\title{
RESPONSE OF INSTRUMENTED BUILDINGS UNDER THE 2016 KAIKŌURA EARTHQUAKE
}

\author{
Reagan Chandramohan ${ }^{1}$, Quincy $\mathrm{Ma}^{2}$, Liam M. Wotherspoon ${ }^{3}$, \\ Brendon A. Bradley ${ }^{4}$, Mostafa Nayyerloo ${ }^{5}$, S. R. Uma $^{6}$ \\ and Max T. Stephens ${ }^{7}$
}

(Submitted March 2017; Reviewed April 2017; Accepted May 2017)

\begin{abstract}
Six buildings in the Wellington region and the upper South Island, instrumented as part of the GeoNet Building Instrumentation Programme, recorded strong motion data during the 2016 Kaikoura earthquake. The response of two of these buildings: the Bank of New Zealand (BNZ) Harbour Quays, and Ministry of Business, Innovation, and Employment (MBIE) buildings, are examined in detail. Their acceleration and displacement response was reconstructed from the recorded data, and their vibrational characteristics were examined by computing their frequency response functions. The location of the BNZ building in the CentrePort region on the Wellington waterfront, which experienced significant ground motion amplification in the 1-2 s period range due to site effects, resulted in the imposition of especially large demands on the building. The computed response of the two buildings are compared to the intensity of ground motions they experienced and the structural and nonstructural damage they suffered, in an effort to motivate the use of structural response data in the validation of performance objectives of building codes, structural modelling techniques, and fragility functions. Finally, the nature of challenges typically encountered in the interpretation of structural response data are highlighted.
\end{abstract}

\section{INTRODUCTION}

Lessons learnt from historical earthquakes have played a vital role in the progressive improvement of our structural design standards. Until a few decades ago, data collected from earthquakes was predominantly qualitative in nature, limited to observations from reconnaissance activities and first-hand accounts of the shaking experienced. In recent years, however, instruments have been increasingly employed to record quantitative data describing the motion of the ground and the response of structures. While ground motion data has been used extensively in seismic hazard and risk assessment, structural response data has seen comparatively limited use.

Recognising the importance and benefits of studying the response of real buildings under earthquakes, GNS Science installed the first array of structural sensors in New Zealand on the Vogel building in Wellington, in 1969 [1; 2]. GNS Science has since installed and maintained sensor arrays on a number of buildings in New Zealand, which have recorded valuable data from many historical earthquakes [1;2]. In 2006, the GeoNet Building Instrumentation Programme [3] was initiated with funding from the New Zealand Earthquake Commission (EQC), with the objective of expanding the structural sensor network to cover a wider variety of buildings, distributed more evenly over the various seismically active regions of New Zealand. This network has demonstrated its worth over the last decade by recording valuable data from the 2010-11 Canterbury earthquake sequence
[4-6], the 2013 Seddon earthquake [7-9], and the 2013 Lake Grassmere earthquake [8]. The 2016 Kaikōura earthquake produced intense ground motion in Wellington [10], with some buildings experiencing ground motions of intensity corresponding to their ultimate limit states as per NZS 1170.5:2004 [11]. Because of a combination of its high population density and large seismic hazard, Wellington currently also contains the densest network of instrumented buildings in New Zealand. This paper summarises the response of instrumented buildings in Wellington, Lower Hutt, and Nelson under the Kaikōura earthquake, as reconstructed from the recorded data.

Comparisons are drawn between the observed damage in the buildings and the damage anticipated from the level of inferred structural response. The inferred response is, in turn, compared to the anticipated response under the observed intensity of ground motion. The utility of such comparisons in the validation of structural modelling techniques and assumptions, building code performance objectives, and fragility functions is motivated. Finally, common challenges encountered in the interpretation of building response data are highlighted.

\section{BUILDING INSTRUMENTATION AND ITS BENEFITS}

Building instrumentation broadly refers to the installation of sensors capable of measuring structural response parameters such as acceleration, displacement, and strain, at strategic locations on the building, with the objective of monitoring specific local

\footnotetext{
${ }^{1}$ Corresponding Author, Lecturer, University of Canterbury, Christchurch, reagan.c@canterbury.ac.nz.(Member)

2 Senior Lecturer, University of Auckland, Auckland, q.ma@auckland.ac.nz (Member)

${ }^{3}$ Senior Lecturer, University of Auckland, Auckland, l.wotherspoon@auckland.ac.nz (Member)

${ }^{4}$ Professor, University of Canterbury, Christchurch, brendon.bradley@canterbury.ac.nz (Member)

5 Seismic Risk Engineer, GNS Science, Lower Hutt, m.nayyerloo@gns.cri.nz (Member)

${ }^{6}$ Earthquake Engineer, GNS Science, Lower Hutt, s.uma@gns.cri.nz.(Member)

7 Postdoctoral Fellow, University of Auckland, Auckland, max.stephens@auckland.ac.nz (Member)
} 
and global modes of structural response. The type, density, and spatial distribution of sensors deployed on a building are largely dictated by $(i)$ the modes of structural response to be monitored; (ii) the required accuracy of structural response reconstruction; (iii) practical restrictions related to physical access, availability of power, and consent of occupants; and (iv) budgetary constraints. Although a number of different types of sensors are available, accelerometers are the most widely used in current practice due to their cost-effectiveness, ease of installation, unobtrusive operation, and the ability to infer structural deformations by the double-integration of recorded acceleration data [12].

There are a number of benefits of monitoring the response of buildings using sensors:

(i) The recorded data can be used to validate structural modelling assumptions, design code performance objectives, and fragility functions [13; 14]. Data from instrumented buildings are better suited to achieving these objectives than data from experimental and numerical investigations, which are limited by necessary practical simplifications and assumptions. For instance, they often use idealised boundary conditions and ignore the effects of nonstructural elements. Laboratory experiments could potentially also be influenced by scale effects.

(ii) The data can help track the evolution in the vibrational characteristics of individual structures, which finds application in short and long-term structural health monitoring [15-19]. The objective of short-term structural health monitoring is to detect and characterise structural damage immediately after an event, thereby informing post-event decisions related to evacuation, placarding, and the need for further inspections. Long-term structural health monitoring, on the other hand, enables the continuous assessment of the ability of a structure to perform its intended function, by tracking the inevitable degradation in its performance over time.

(iii) Structural response data can be used to identify the factors contributing to any damage observed during an earthquake, thereby helping resolve any legal disputes that may consequently arise.

(iv) Ambient vibration and strong motion data are often used to calibrate numerical models of individual structures $[6 ; 20$ 24], which permit the refinement of seismic loss and risk estimates. Larger community-level models comprising of a number of such individual building models could then be used to conduct community-level seismic risk assessments and help guide disaster response efforts following an event [25]. Such models are likely to play a vital role in the planning and administration of future smart cities.

\section{KAIKŌURA EARTHQUAKE}

The $M_{W} 7.8$ Kaikōura earthquake struck at 00:03 on 14 November 2016 NZDT, with an epicentre located about $7 \mathrm{~km}$ North of the rural town of Waiau, in the South Island of New Zealand, at a depth of $15 \mathrm{~km}$. The rupture then propagated unilaterally in the North Eastern direction, for about $150 \mathrm{~km}$ along the North Eastern coast of the South Island, jumping over multiple fault segments before terminating near Cape Campbell after about $70 \mathrm{~s}$ (Figure 1a) [26-29]. Population centres that experienced the strongest levels of ground motion, and consequently suffered the most significant societal impacts include Kaikōura, Blenheim, and Wellington. Wellington-the largest of these population centres-is located approximately $60 \mathrm{~km}$ North East of the closest ruptured fault segment. The relatively strong shaking witnessed in Wellington despite its moderate distance from the source, is attributed primarily to the amplification of ground motion by the deep sediments and basins underlying the city. Wellington's location in the path of focussed seismic waves along the direction of rupture (Figure 1a) is expected to have played a secondary role. Local site amplification effects are considered to be particularly responsible for the strong energy content in the 1-2 s period range observed in several ground motions recorded in Wellington (e.g., Figures 2b, 2d and 2e), although the attenuation of high frequency content over distance is also expected to have contributed to this effect. This amplification was most pronounced at sites located on deep soil deposits along the Wellington waterfront (e.g., Figures $2 b$ and 2d) [10; 30]. The durations of the recorded ground motions, as quantified by the 5-95\% significant duration metric, $D s_{5-95}$ [31], range from $20-30 \mathrm{~s}$. The high energy content in the $1-2 \mathrm{~s}$ period range, coupled with the moderately long ground motion duration, resulted in damage to a number of mid and highrise buildings, while lowrise buildings were relatively unaffected [32]. Some of the damaged mid and highrise buildings continue to remain closed four months since the earthquake, while others have already been demolished.

\section{RESPONSE OF INSTRUMENTED BUILDINGS}

\section{Overview}

GeoNet maintains structural instrument arrays on a number of buildings in New Zealand cities that possess high seismic hazard levels. Buildings are chosen for instrumentation so as to cover a wide range of materials, structural systems, and configurations. A balance is also maintained between tall or special buildings fitted with seismic protection devices, and ordinary buildings that are representative of the typical building stock in New Zealand [33]. GeoNet currently monitors a total of 14 buildings and 3 bridges, distributed over the Wellington region, Christchurch, Nelson, Napier, and Levin. All buildings are fitted with either CUSP-M or CUSP-Me MEMS accelerometers developed by Canterbury Seismic Instruments. Free-field accelerometers are installed on the ground beside some of the buildings to enable the assessment of soil-structure-interaction effects. The locations of five instrumented buildings in Wellington and two buildings outside Wellington, that experienced strong motion from the Kaikōura earthquake, are indicated in Figure 1. Detailed information about each of these buildings, except the Majestic Centre building, is provided in Table 1. A description of the 29-storey tall Majestic Centre building-the tallest building in Wellington-and its response under the Kaikōura earthquake could not be included in this paper due to contractual restrictions on the publication of recorded building response data. Such limitations on the dissemination of information potentially valuable to the Structural Engineering community represent a major stumbling block in the use of structural response data in research. Site soil classification information for the buildings located in Wellington were obtained from Semmens et al. [34]; information for the GNS Science and Nelson Marlborough Institute of Technology (NMIT) Arts \& Media buildings were obtained from Boon et al. [35] and QMAP [36] respectively. The response of all these buildings was captured by the installed sensors, except the Victoria University Te Puni Village building, which experienced a data logger failure.

\section{Base Ground Motions}

The $5 \%$ damped pseudo-acceleration response spectra of the ground motions recorded at the base of the instrumented buildings, along their longitudinal and transverse axes, are plotted in Figure 2 using red and grey solid lines respectively. These response spectra are plotted against the 500 year return period 


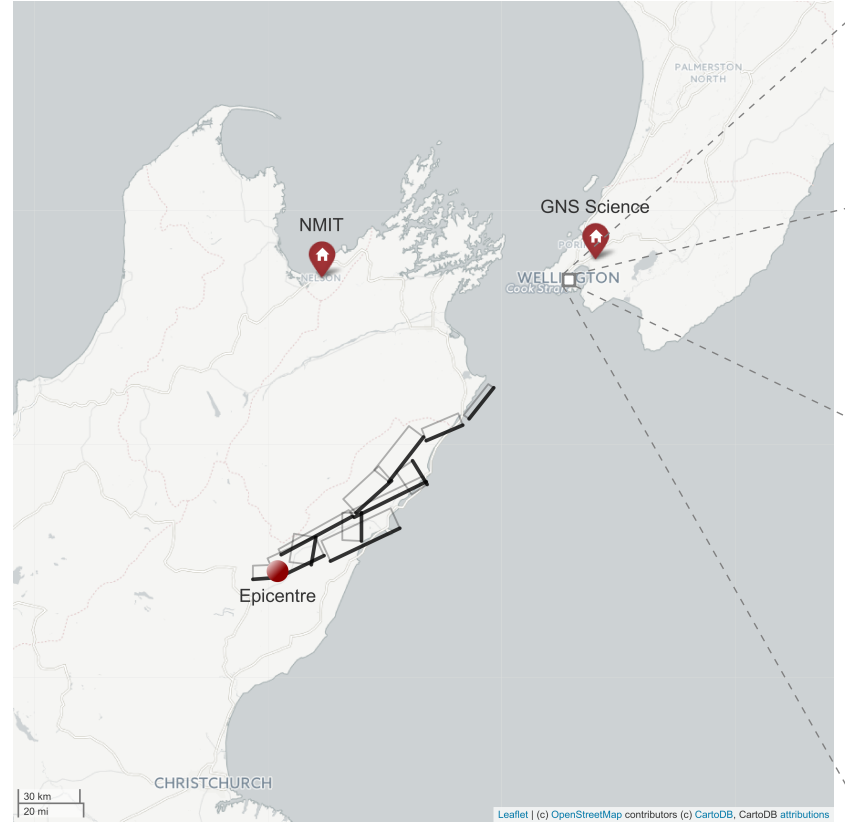

(a)

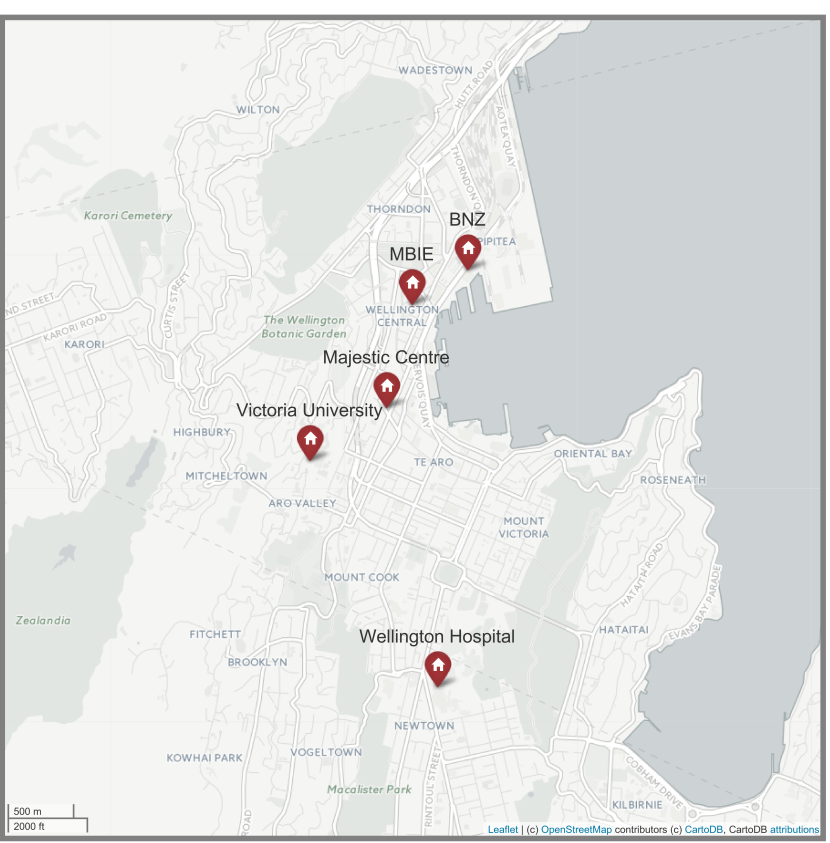

(b)

Figure 1: Locations of instrumented buildings (a) outside and (b) inside Wellington that recorded the 2016 Kaikoura earthquake, with respect to the epicentre and ruptured faults.

Table 1: Details of instrumented buildings (except the Majestic Centre building) that recorded strong motion from the 2016 Kaikōura earthquake.

\begin{tabular}{|c|c|c|c|c|c|c|c|c|}
\hline Building & $\begin{array}{c}\text { GeoNet } \\
\text { identifier }\end{array}$ & Location & $\begin{array}{l}\text { No. of } \\
\text { levels }\end{array}$ & $\begin{array}{l}\text { Lateral load } \\
\text { resisting system }\end{array}$ & $\begin{array}{l}\text { Site } \\
\text { class }\end{array}$ & $\begin{array}{c}\text { Year } \\
\text { constructed }\end{array}$ & $\begin{array}{c}\text { Year } \\
\text { instrumented }\end{array}$ & Instrumentation details \\
\hline GNS Science & AVAB & Lower Hutt & $\begin{array}{l}3 \text { storeys }+ \\
1 \text { basement }\end{array}$ & $\begin{array}{l}\text { Reinforced } \\
\text { concrete moment } \\
\text { frame }\end{array}$ & $\mathrm{D}$ & 1973 & 2007 & $\begin{array}{l}9 \text { structural and } 1 \\
\text { free-field triaxial } \\
\text { accelerometer }\end{array}$ \\
\hline $\begin{array}{l}\text { Bank of New Zealand } \\
\text { (BNZ) Harbour } \\
\text { Quays }\end{array}$ & CPLB & Wellington & 5 storeys & $\begin{array}{l}\text { Reinforced } \\
\text { concrete moment } \\
\text { frame }\end{array}$ & $\mathrm{D}$ & 2009 & 2009 & $\begin{array}{l}14 \text { structural and } 1 \\
\text { free-field triaxial } \\
\text { accelerometer }\end{array}$ \\
\hline $\begin{array}{l}\text { Nelson Marlborough } \\
\text { Institute of } \\
\text { Technology (NMIT) } \\
\text { Arts \& Media }\end{array}$ & NMIB & Nelson & 3 storeys & $\begin{array}{l}\text { Timber shear } \\
\text { walls with energy } \\
\text { dissipating } \\
\text { devices }\end{array}$ & $\mathrm{D}$ & 2011 & 2011 & $\begin{array}{l}9 \text { structural and } 1 \\
\text { free-field triaxial } \\
\text { accelerometer, } 13 \\
\text { LVDTs, and } 1 \text { weather } \\
\text { station }\end{array}$ \\
\hline $\begin{array}{l}\text { Ministry of Business, } \\
\text { Innovation, and } \\
\text { Employment (MBIE) }\end{array}$ & STSB & Wellington & $\begin{array}{l}8 \text { storeys }+ \\
1 \text { basement }\end{array}$ & $\begin{array}{l}\text { Concrete-encased } \\
\text { steel moment } \\
\text { frame }\end{array}$ & $\mathrm{C}$ & 1940 & 2014 & 16 triaxial accelerometers \\
\hline $\begin{array}{l}\text { Victoria University Te } \\
\text { Puni Village }\end{array}$ & VUWB & Wellington & 10 storeys & $\begin{array}{l}\text { Rocking steel } \\
\text { moment frame }\end{array}$ & B & 2009 & 2009 & $\begin{array}{l}12 \text { triaxial } \\
\text { accelerometers, } 5 \text { LVDTs, } \\
\text { and } 1 \text { weather station }\end{array}$ \\
\hline Wellington Hospital & WHSB & Wellington & $\begin{array}{l}6 \text { storeys }+ \\
1 \text { basement }\end{array}$ & $\begin{array}{l}\text { Base-isolated } \\
\text { reinforced } \\
\text { concrete moment } \\
\text { frame }\end{array}$ & $\mathrm{C}$ & 2008 & 2009 & 16 triaxial accelerometers \\
\hline
\end{tabular}

and 25 year return period elastic design spectra of the respective structures computed as per NZS 1170.5:2004 [11, Section 3]. Assuming a design working life of 50 year and an importance level of 2 for all structures, the 500 year return period ground motion corresponds to their Ultimate Limit State (ULS), while the 25 year return period ground motion corresponds to their Serviceability Limit State (SLS). Two of the instrumented buildings - the GNS Science and MBIE buildings-were de- signed before 2004: the year the current revision of the New Zealand building code came into effect. Of the two, the MBIE building was demonstrated to possess a capacity in excess of the current code requirements after its redevelopment in 2014, using in-situ testing [37]. Hence, comparison of the base ground motions to the NZS1170.5:2004 design spectra is considered instructive for context. The 5-95\% significant durations, $D s_{5-95}$, of the recorded ground motions are indicated in parentheses in 
the legend. The fundamental modal periods of the buildings in each orthogonal direction, as inferred from their computed frequency response functions (discussed below), are indicated using vertical dotted lines. Although these fundamental periods are likely to be slightly different from those used to compute the design loads during the structural design phase, they are considered adequate to qualitatively judge the fraction of the design loads the buildings were subjected to during the earthquake. The response spectral ordinates at the fundamental periodsplotted as circles in Figure 2-indicate that the intensities of ground motion experienced by the NMIT and Wellington Hospital buildings corresponded roughly to their serviceability limit states. The intensities of ground motion experienced by the GNS Science and MBIE buildings were lower and higher than the serviceability limit state respectively. The level of ground motion experienced by the BNZ building, on the other hand, was approximately equivalent to the ultimate limit state. To facilitate a comparison to the intensity of ground motion these buildings previously experienced under the $M_{W} 6.5$ Seddon and $M_{W} 6.5$ Lake Grassmere earthquakes in 2013, similar plots corresponding to these two earthquakes have been placed in Figures A2 and A3 of the appendix to this paper respectively, which is available at http://hdl.handle.net/10092/13311.

Among the five buildings whose response under the Kaikōura earthquake was recorded, the GNS Science, NMIT, and Wellington Hospital buildings can been seen from Figure 2 to have experienced relatively low intensity ground motions. The deformation and acceleration response of the Wellington Hospital building superstructure was further reduced by its base-isolation devices. Besides being temporarily closed for initial inspections, these three buildings also suffered no noticeable damage or disruption from the earthquake. A discussion of their response is, therefore, excluded from this paper, although plots summarising their response are available in Figures A5-A9 of the appendix. The rest of this paper focusses exclusively on the response of the BNZ and MBIE buildings.

\section{The Bank of New Zealand (BNZ) Harbour Quays Building}

The BNZ Harbour Quays building is a modern five-storey building with a total floor area of about $25,000 \mathrm{~m}^{2}$ (Figure $3 \mathrm{a}$ ). The building consists of three structurally independent bays separated by two atria. Reinforced concrete perimeter moment frames serve as the lateral load resisting system. Precast hollow-core floor systems span a distance of $17 \mathrm{~m}$ between the perimeter frames. The schematic of the building is illustrated in Figure $4 \mathrm{a}$ along with the locations of the installed accelerometers. The building is located in the CentrePort region on the Wellington waterfront, which experienced consistently stronger ground motion than the rest of the city during the 2013 Seddon and Lake Grassmere earthquakes, as well as the 2016 Kaikōura earthquake (Figure 2 and Figures A2 and A3 of the appendix) [10; 27; 28]. The phenomenon of consistent ground motion amplification in this region-particularly in the $1-2 \mathrm{~s}$ period range - is attributed to the deep underlying soil deposits $[30 ; 38]$. The region also witnessed events of liquefaction, lateral spreading, and settlement: a repeated observation from a number of historical earthquakes [30; 38]. The building previously suffered significant nonstructural damage during the 2013 Seddon earthquake, following which, it was closed for several months for repairs [39; 40]. The building was damaged again during the Kaikōura earthquake [32]. Structural damage under the Kaikōura earthquake included spalled concrete columns and cracks in beams and floor slabs at the column joints, while nonstructural damage included broken glass facades and gib board, detached doors, failed ceiling panels, and dislodged floor tiles [32; 41-43]. The building currently remains closed for repairs, four months after the earthquake [44].
The observation that the building experienced ground motion of intensity approximately equivalent to the ultimate limit state as per [11] (Figure 2b), and satisfactorily achieved the life-safety objective stated in [45, Section C2.1], offers one data point towards the validation of the specific code performance objective. Although the level of observed nonstructural damage possessed the potential to cause injuries and fatalities, the fact that the building was largely unoccupied at the time the earthquake struck enabled the achievement of the life-safety objective. These observations serve to highlight the important role of instrumented buildings in aiding the validation of code performance objectives.

\section{The Ministry of Business, Innovation, and Employment (MBIE) Building}

The MBIE building on Stout Street is an eight-storey building originally built in the early 1940s and redeveloped in 2014 (Figure $3 b$ ). It has a total floor area of about $21,000 \mathrm{~m}^{2}$. Its structural system consists of concrete-encased steel moment frames and cast-in-place reinforced concrete floor slabs. A structural steel framed internal atrium and monitoring sensors were added during the redevelopment in 2014. The schematic of the building is illustrated in Figure $4 \mathrm{~b}$ along with the locations of the installed accelerometers. The building is observed in Figure 2d to have experienced a level of ground motion more intense than that corresponding to the serviceability limit state as per [11]. The response spectral ordinates at periods below and above the fundamental period-corresponding to higher mode response and softening nonlinear response respectively-however, are much higher in comparison to the SLS design spectrum. Since ground motion energy content at these shorter and longer periods have also been shown to influence structural response [48], the building could be judged to have experienced a level of ground motion substantially higher than that corresponding to the serviceability limit state, but still lower than the ultimate limit state. The building suffered negligible structural damage including minor cracks in the concrete slab and basement slab, and some nonstructural damage including broken and dislodged glass windows, dislodged wall tiles, and cracked plaster walls [49;50]. Some external damage was attributed to pounding against the adjacent Te Puni Kokiri building [50]. It was, nevertheless, deemed occupiable immediately after an initial inspection, although the atrium remained closed until January 2017. Although the building was capable of fully serving its intended function immediately following the earthquake, the observed level of damage is considered to have exceeded the serviceability limit state, at which contact with another structure is not permitted [11, Section 7.5.2].

\section{Response of the BNZ and MBIE Buildings Inferred from Recorded Data}

The first step in reconstructing the response of the buildings was to subtract any static offsets and filter the recorded accelerograms based on the recommendations of Boore [51] and Boore and Bommer [52]. Corner frequencies of $0.1 \mathrm{~Hz}$ and $20 \mathrm{~Hz}$ were used in the filtering process. The presence of significant highfrequency noise in some of the records necessitated the use of a high-cut filter in addition to the traditionally employed low-cut filter. The two orthogonal horizontal components of each record were then rotated to coincide with the longitudinal and transverse axes of each building.

A common assumption made in order to infer the horizontal acceleration response at any point on a building level based on measurements made by instruments located at other discrete locations on the same level, is that of a rigid diaphragm [53]. Use of the rigid diaphragm assumption requires three linearly 


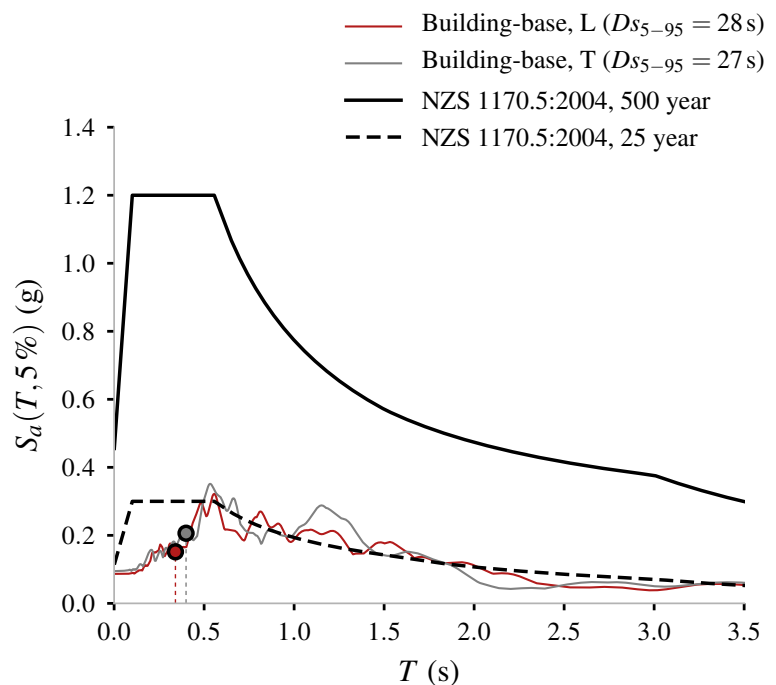

(a) GNS Science building

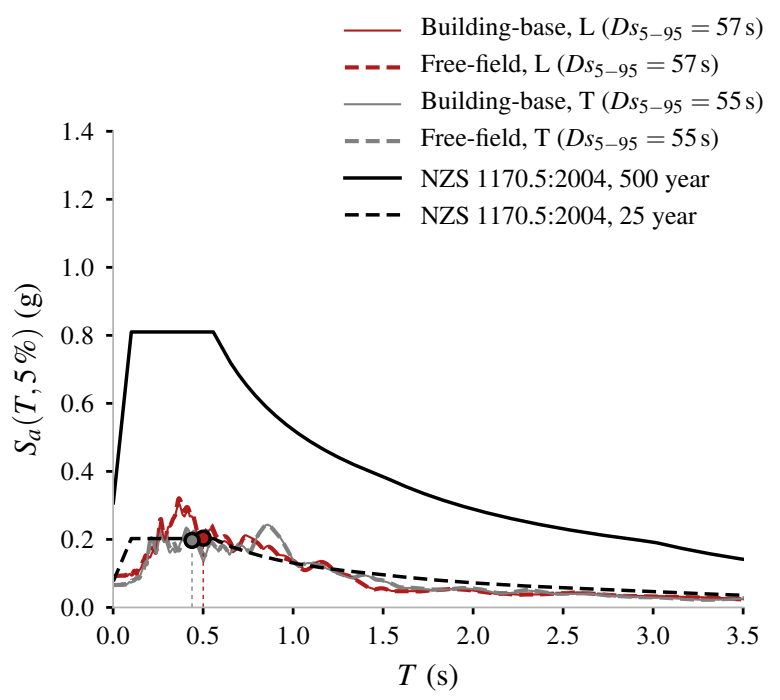

(c) NMIT building

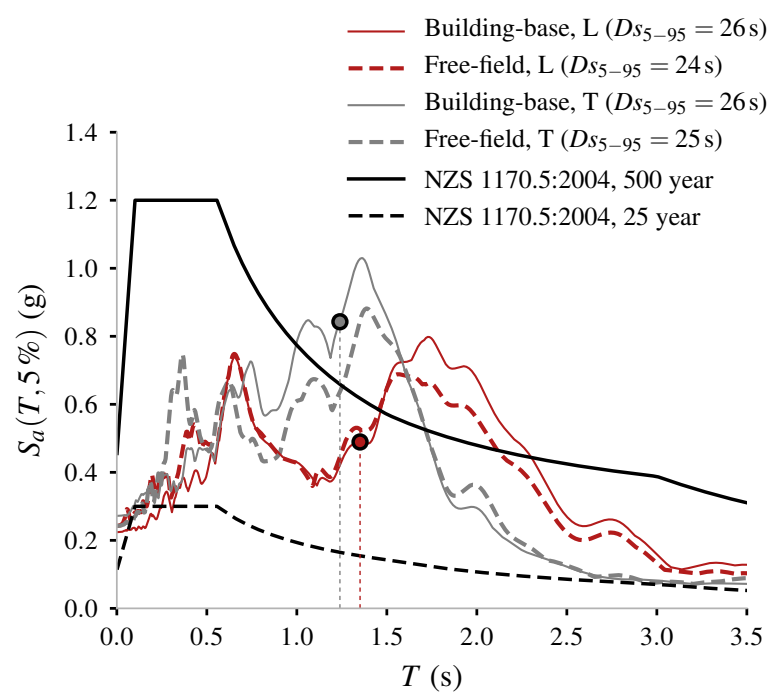

(b) BNZ building

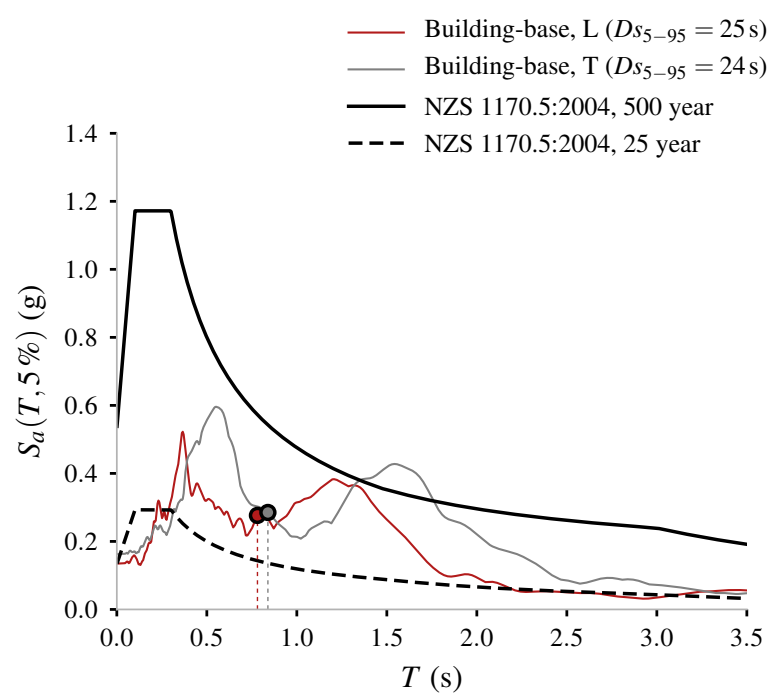

(d) MBIE building

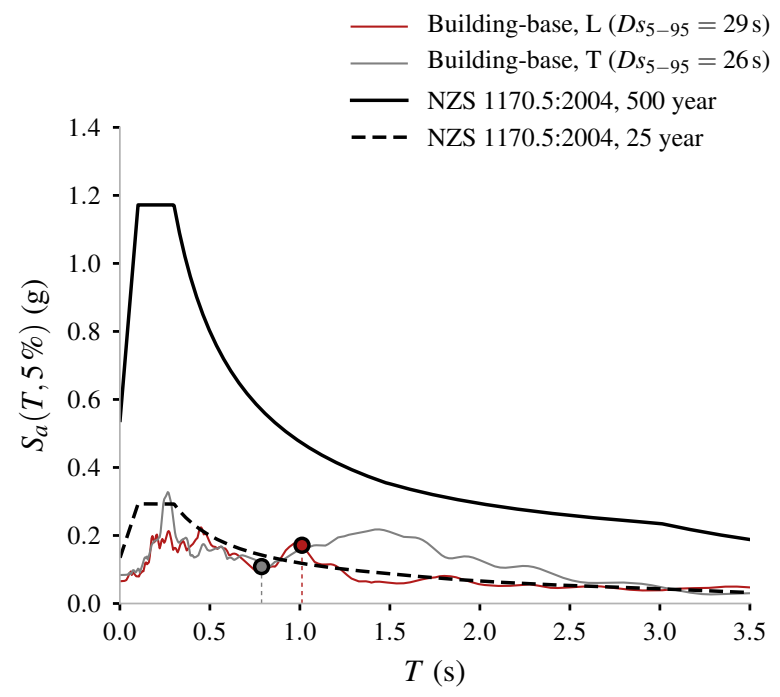

(e) Wellington Hospital building

Figure 2: Response spectra of the building-base and free-field (where available) ground motions in the longitudinal (L) and transverse (T) directions produced by the 2016 Kaikōura earthquake. Comparison to the 500 year and 25 year return period NZS 1170.5:2004 elastic design spectra is provided for context. The fundamental periods inferred from frequency response functions are indicated using vertical dotted lines and building-base response spectral ordinates at these periods are indicated using circles. $D s_{5-95}$ values of the ground motions are indicated in parentheses. 


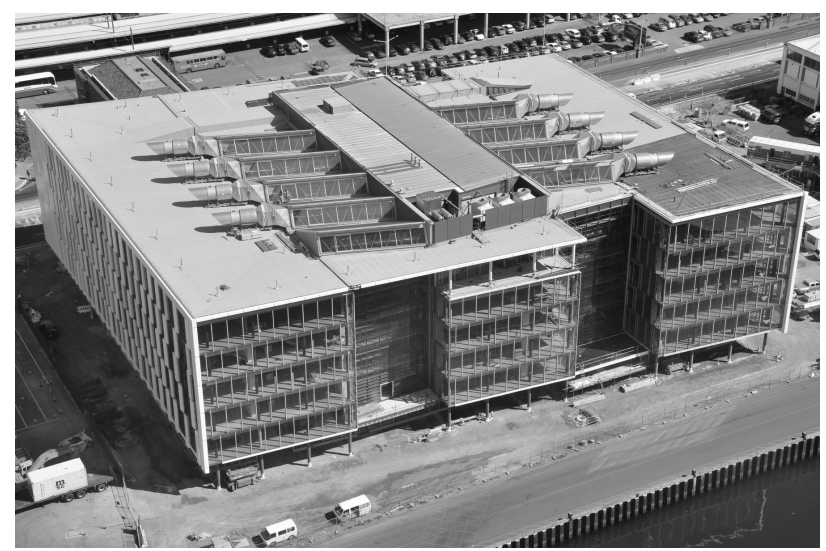

(a) BNZ building (view from the South) [46]

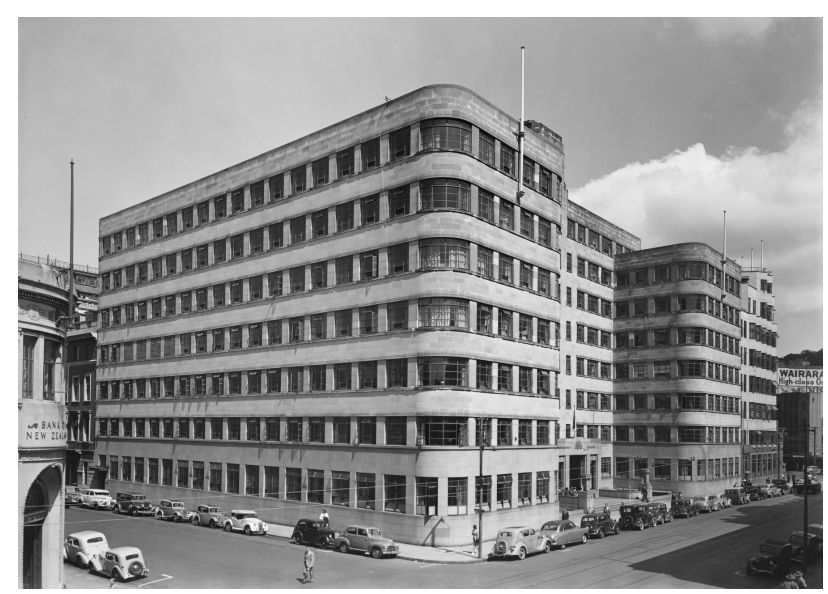

(b) MBIE building (view from the North) [47]

Figure 3: Photographs of instrumented buildings (Additional photographs are available in Figure A1 of the appendix).

independent measurements of horizontal acceleration in cases where the torsional response of the building is comparable to the translational response. In cases where the torsional response can be assumed to be relatively insignificant, however, two linearly independent measurements are sufficient. When more than the required number of linearly independent measurements are available at a level, the system is overdetermined, and a least-squares solution can be computed for the acceleration response at any point at that level. Given the high costs associated with building instrumentation and the practical limitations of data acquisition hardware, however, the alternate scenario of having fewer than the required number of linearly independent measurements at a level is more frequently encountered. In such a situation, Naeim et al. [53] recommends the vertical interpolation of the missing acceleration components, if the same components have been recorded at levels above and below it.

\section{Acceleration Response}

Since Bays 1 and 2 of the BNZ building are too sparsely instrumented for accurate response reconstruction, only the response of Bay 3 is computed (Figure 4a). At each level of Bay 3, the motion at the vertical axis along which sensors 3, 4, 5, 6, and 8 are installed is considered representative of the motion of the entire level, assuming the torsional response to be insignificant. This assumption is necessary since only two orthogonal components are recorded at most levels. At levels G, 1, 2, 3, and 4 , the recordings of sensors $3,4,5,6$, and 8 respectively are used as is. At level 5, the recording of sensor 10 in the longitudinal direction is used in conjunction with that of sensor 11 in the transverse direction, in order to negate the influence of any torsional motion, if present. Since the horizontal line joining the location of sensor 10 to the point of intersection of the considered vertical axis and the $5^{\text {th }}$ level is parallel to the longitudinal axis of the building, the two points will experience the same longitudinal motion even if a non-negligible torsional component of response exists. The location of sensor 11 and the vertical axis will experience the same transverse motion for a similar reason. Recordings from sensors 9 and 15 were not used since they were found to contain spurious high-frequency artefacts as illustrated in Figure 5. These artefacts could not be completely eliminated using a high-cut filter. Sensors 15 is, additionally, observed to have not recorded any data from around $87-90 \mathrm{~s}$. The source of these artefacts cannot be easily determined without conducting a more detailed investigation. Nevertheless, they serve to highlight a challenge commonly encountered when interpreting structural response data: handling records with low signal-to-noise ratios.
The acceleration time series computed in the transverse direction at each level are plotted in Figure 6a. Time series analogously computed in the longitudinal direction have been placed in Figure A4 of the appendix. The peak floor acceleration (PFA) at each level and direction is then computed as the maximum absolute acceleration over the entire time series. The variation in PFA along the height of the building in both orthogonal directions is plotted in Figures $7 \mathrm{a}$ and $7 \mathrm{~b}$ using solid lines. These PFA values could have occurred at different times at different levels and directions. PFAs experienced by the building under the 2013 Seddon and Lake Grassmere earthquakes are overlaid on this and subsequent plots using dotted lines to enable a comparison of the response of the building to the different earthquakes. The building is observed to have experienced larger PFAs under the Kaikōura earthquake in both directions, as expected from an earthquake of significantly larger magnitude. The amplification of PFA over the height of the building is also evident from both plots. A maximum PFA of around $0.8 \mathrm{~g}$ is observed at the fifth level, in the transverse direction.

The response of the MBIE building is similarly computed at the vertical axis along which sensors $1,2,4,5,7,12,13,14$, and 15 are installed. No sensors are, however, installed along this axis at levels 3 and 5. At level 3, the recordings of sensor 6 are used despite the potential for discrepancies in the presence of significant torsional motion, highlighting the nature of challenges frequently encountered due to sparsity of instrumentation. At level 5, a linear combination of the recordings of sensors 8 and 11 in proportion to their respective distances from the vertical axis is used. The computed acceleration time series and PFAs are plotted in Figures 6b, 7c and 7d. There appears to be an obvious inconsistency at level 3 (at a height of about $12 \mathrm{~m}$ from ground level) in each of these plots, which is likely an indicator of non-negligible torsional response. The maximum PFA experienced by this building is around $0.4 \mathrm{~g}$ at the roof level, in both longitudinal and transverse directions. No data regarding the response of this building to the 2013 Seddon and Lake Grassmere earthquakes is available since it was instrumented only in July 2014.

\section{PFA/PGA Ratio}

The PFA at a level determines the peak dynamic shear force experienced by objects secured to that level, and hence, is an important parameter that influences the design of accelerationsensitive nonstructural components. NZS 1170.5:2004 [11, Section 8] uses a bilinear, empirically determined design equation to model the variation in the ratio of the PFA and the design peak 

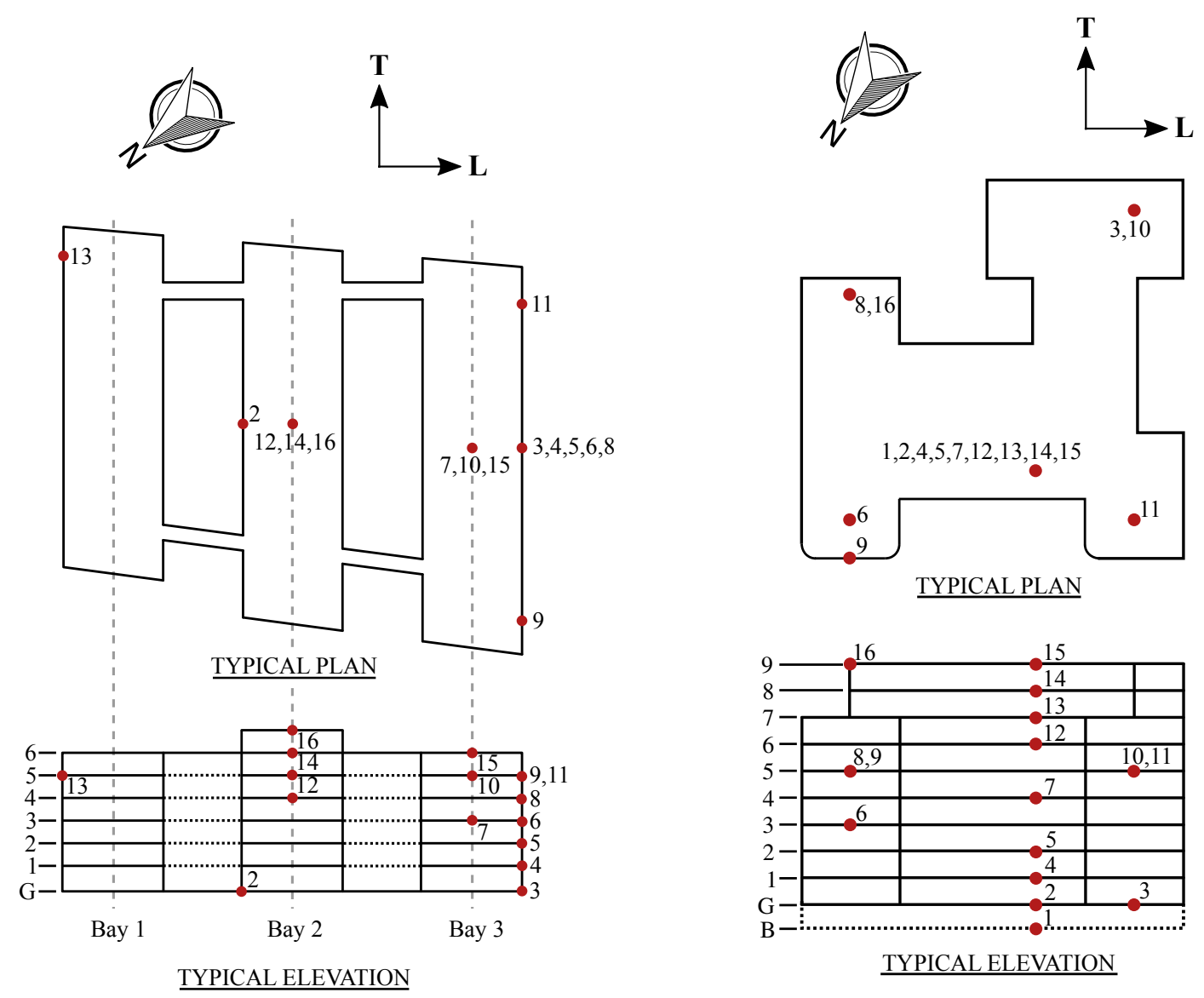

TYPICAL PLAN

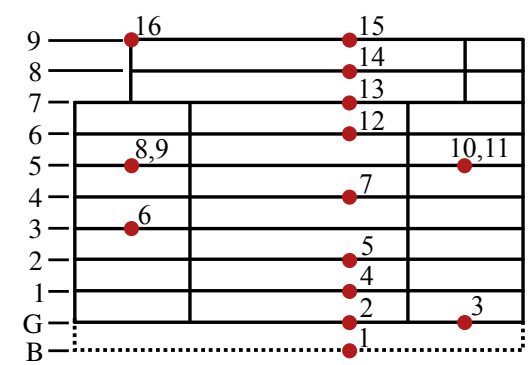

TYPICAL ELEVATION

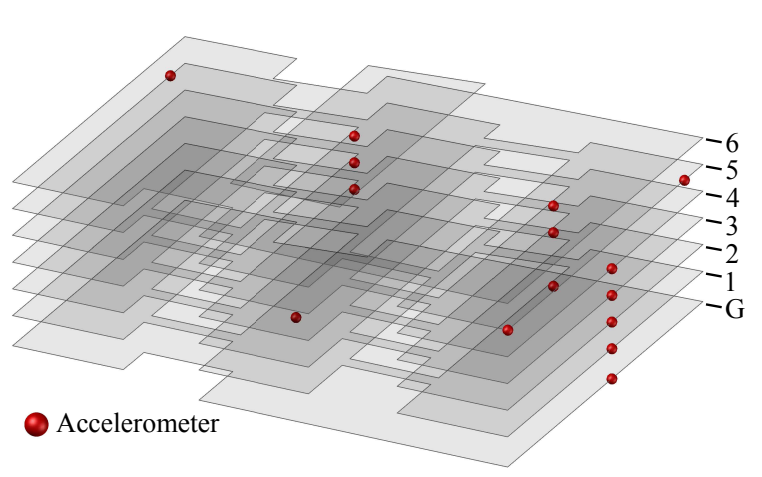

3D PERSPECTIVE

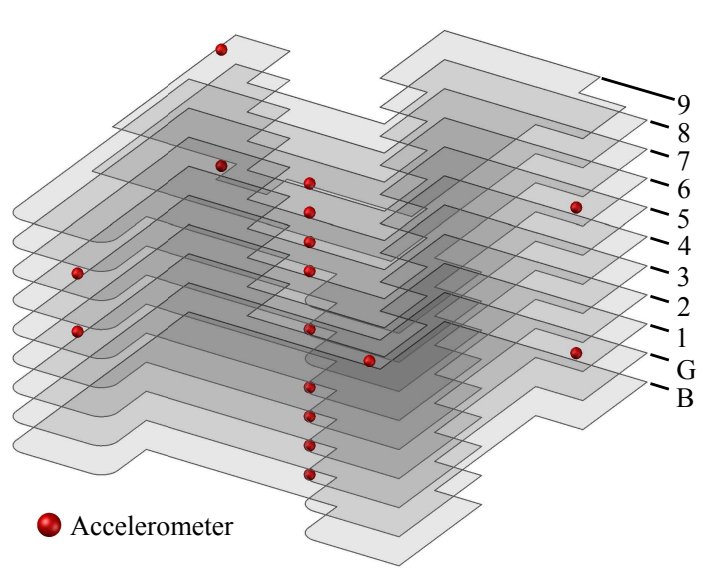

3D PERSPECTIVE

(a) BNZ building

(b) MBIE building

Figure 4: Schematics depicting the locations of installed triaxial accelerometers, along with the orientations of the buildings' longitudinal and transverse axes.

ground acceleration (PGA) over the height of the building. The PFA/PGA ratios observed in the two buildings are plotted against the simplified bilinear design relation in Figure 8. Although the design relation appears to be conservative for these two buildings, similar curves plotted for the GNS Science and NMIT buildings, available in Figure A6 of the appendix, indicate that this may not always be the case. These results are consistent with those obtained previously by Thomson and Bradley [8] for the Seddon and Lake Grassmere earthquakes. A comparison of the PFAs experienced by the Wellington Hospital building to the design relation is not appropriate since the building is base-isolated. An important assumption made here is that the PFA/PGA profile is not significantly influenced by the actual PGA value, thereby enabling a comparison of the PFA/PGA profiles even for buildings that did not experience design level ground motions. This data could potentially also be used to validate other models for the variation in PFA over the height of buildings, like Drake and Bragagnolo [54]; Rodriguez et al. [55]; Miranda and Taghavi [56].

\section{Displacement Response}

The displacement time series at each level is computed by integrating the acceleration time series at that level over time, twice. 


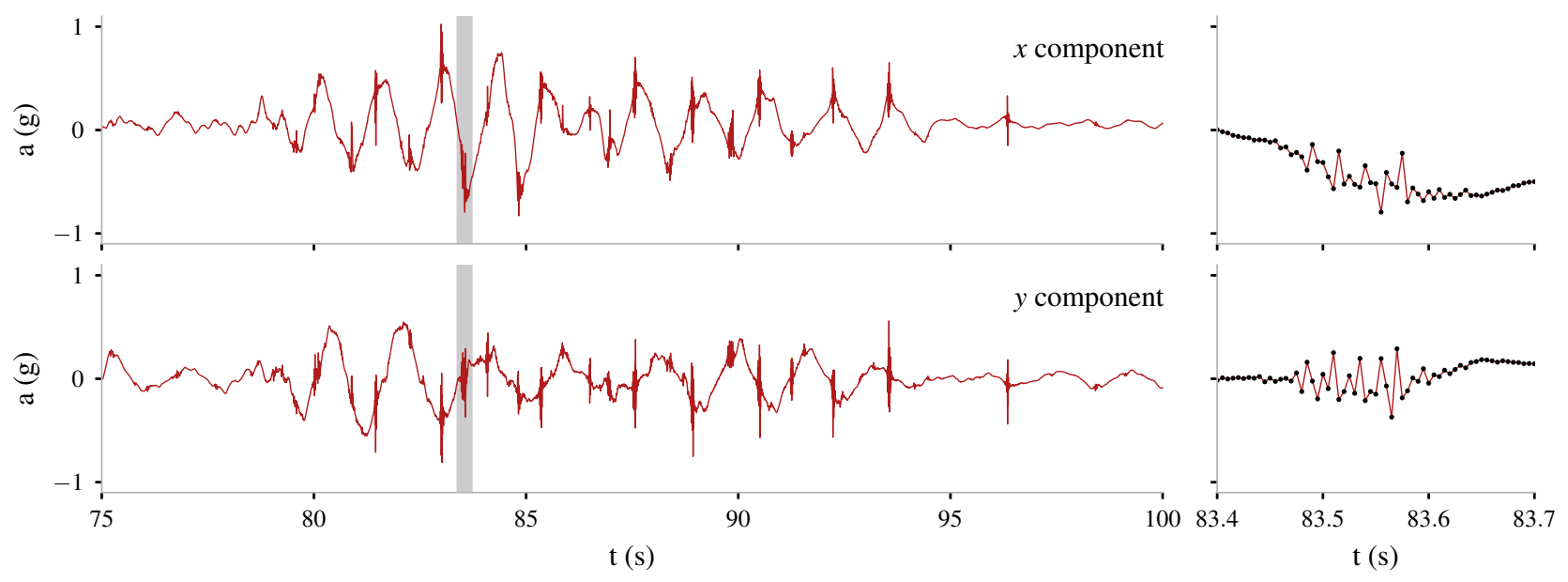

(a) Sensor 9
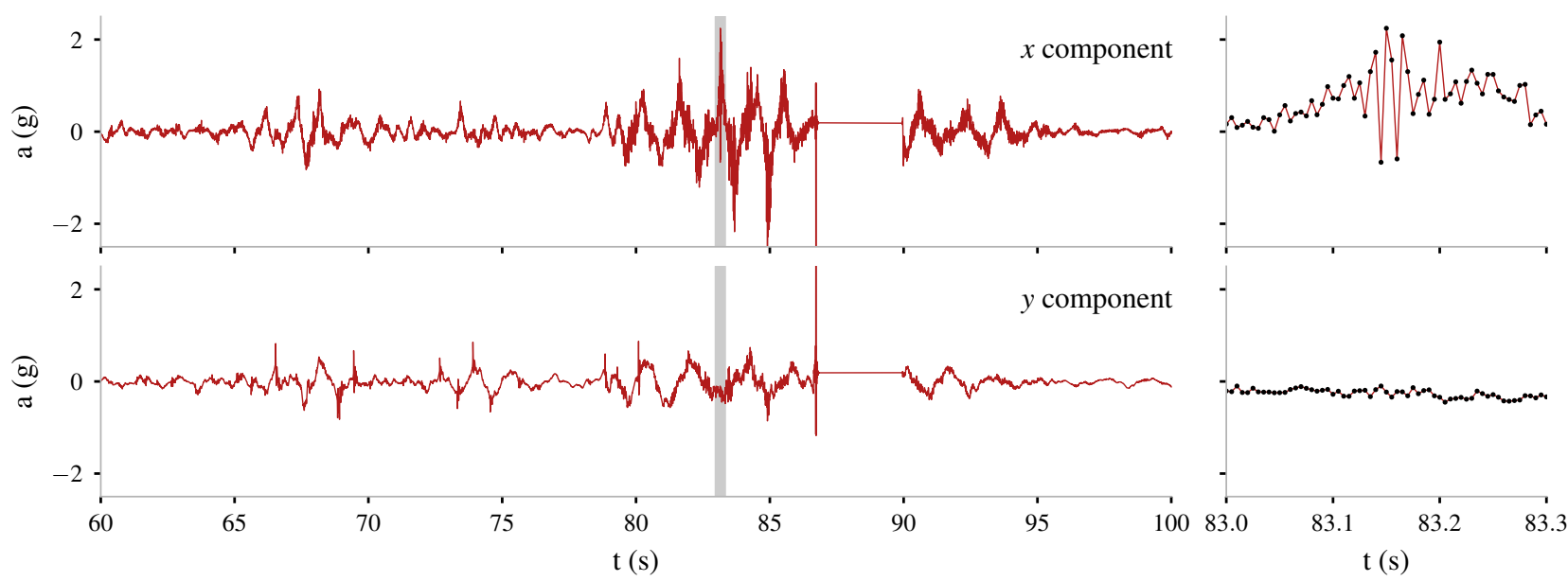

(b) Sensor 15

Figure 5: Unfiltered records from the BNZ building containing spurious artefacts. The plots on the right show the regions shaded in grey in the plots on the left, in additional detail.

This method of inferring displacements indirectly from acceleration records, however, has some important drawbacks. The inferred displacements are sensitive to the manner in which the acceleration records are processed. Specifically, the use of a low-cut filter to eliminate drifts in the displacement and velocity traces effectively also eliminates all information regarding residual structural deformations. In this study, the removal of static offsets and use of a low-cut filter with corner frequency $0.1 \mathrm{~Hz}$ was capable of successfully eliminating all drifts in the displacement traces computed by double-integration, without the need for additional baseline correction [52]. Although alternative devices that permit the direct measurement of displacement by contact and non-contact methods do exist, there are a number of unresolved practical issues that limit their use [12].

The relative displacement time series at a level with respect to the ground is computed as the difference between the displacement time series at that level and the ground. The peak relative displacement at the level is then computed as the maximum absolute relative displacement over time. The variation of peak relative displacement over the height of the building is plotted in Figure 9. The peak relative displacements at different levels could have occurred at different instants of time.

The storey drift ratio (SDR) time series of each storey is com- puted as the difference between the displacement time series of the upper and lower levels constituting the storey, normalised by the storey height. The peak SDR of a storey is then computed as the maximum absolute SDR at that storey over the entire time series. The variation in the computed peak SDR over all stories is plotted in Figure 10. Like peak floor accelerations and relative displacements, peak SDRs at different stories could also have occurred at different instants of time.

Peak SDR is a measure of the maximum lateral deformation experienced by a storey, and has been shown to be well correlated to the damage observed in structural components and deformation-sensitive nonstructural elements. NZS 1170.5:2004 permits a maximum peak SDR of no more than $2.5 \%$ at the ultimate limit state [11, Section 7.5.1]. A maximum peak SDR of $1.8 \%$ is observed in the BNZ building at the ultimate limit state, indicating compliance with the prescribed code limits and aiding the validation of the code performance objective relating to storey drifts. This large observed peak SDR value, however, corroborates the level of structural damage observed in the building. The peak SDRs in the MBIE building are observed to be around $0.2 \%$ over the entire height of the building. The inconsistency in the data used at level 3 of the MBIE building appears to manifest in the SDRs computed at both the third and fourth storeys. This relatively low level of lateral deformation supports the observa- 


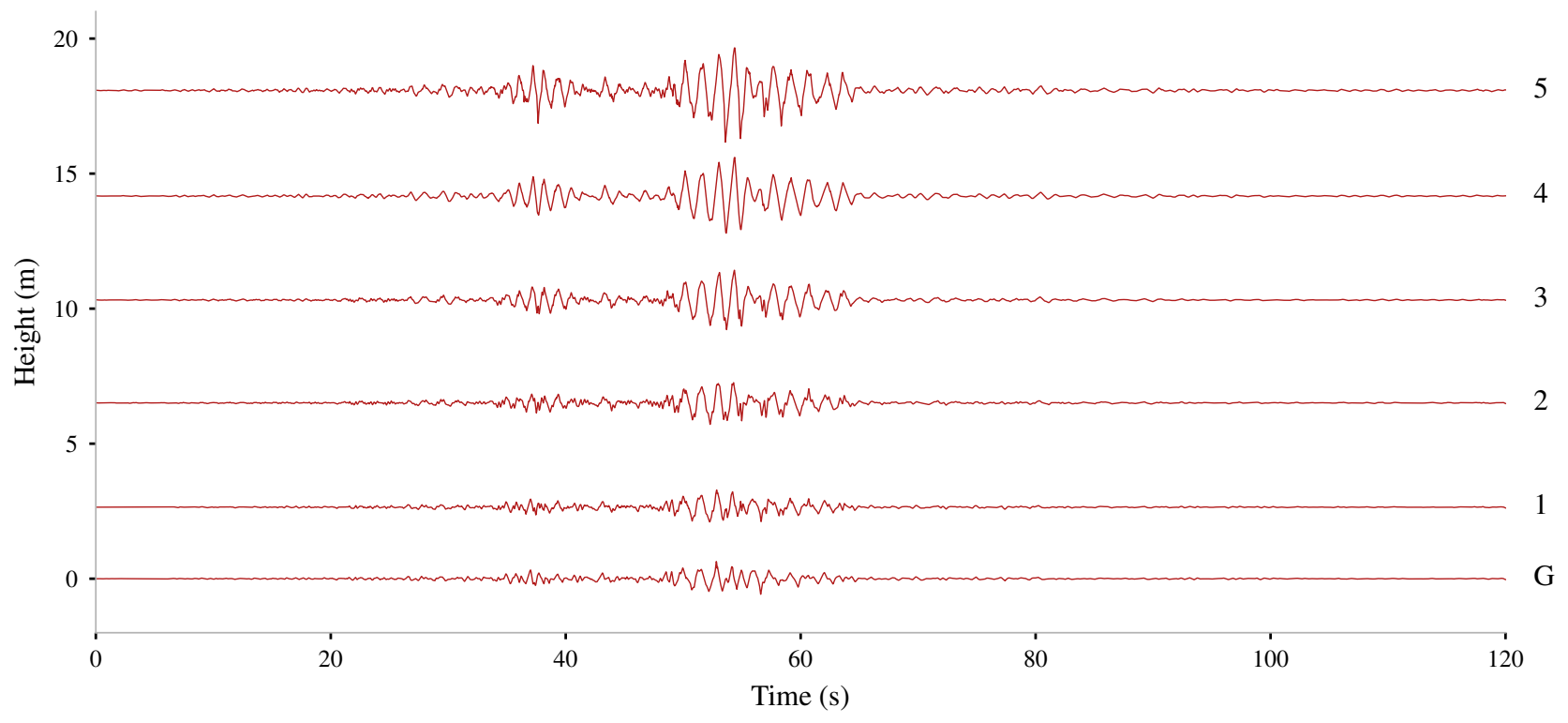

(a) BNZ building

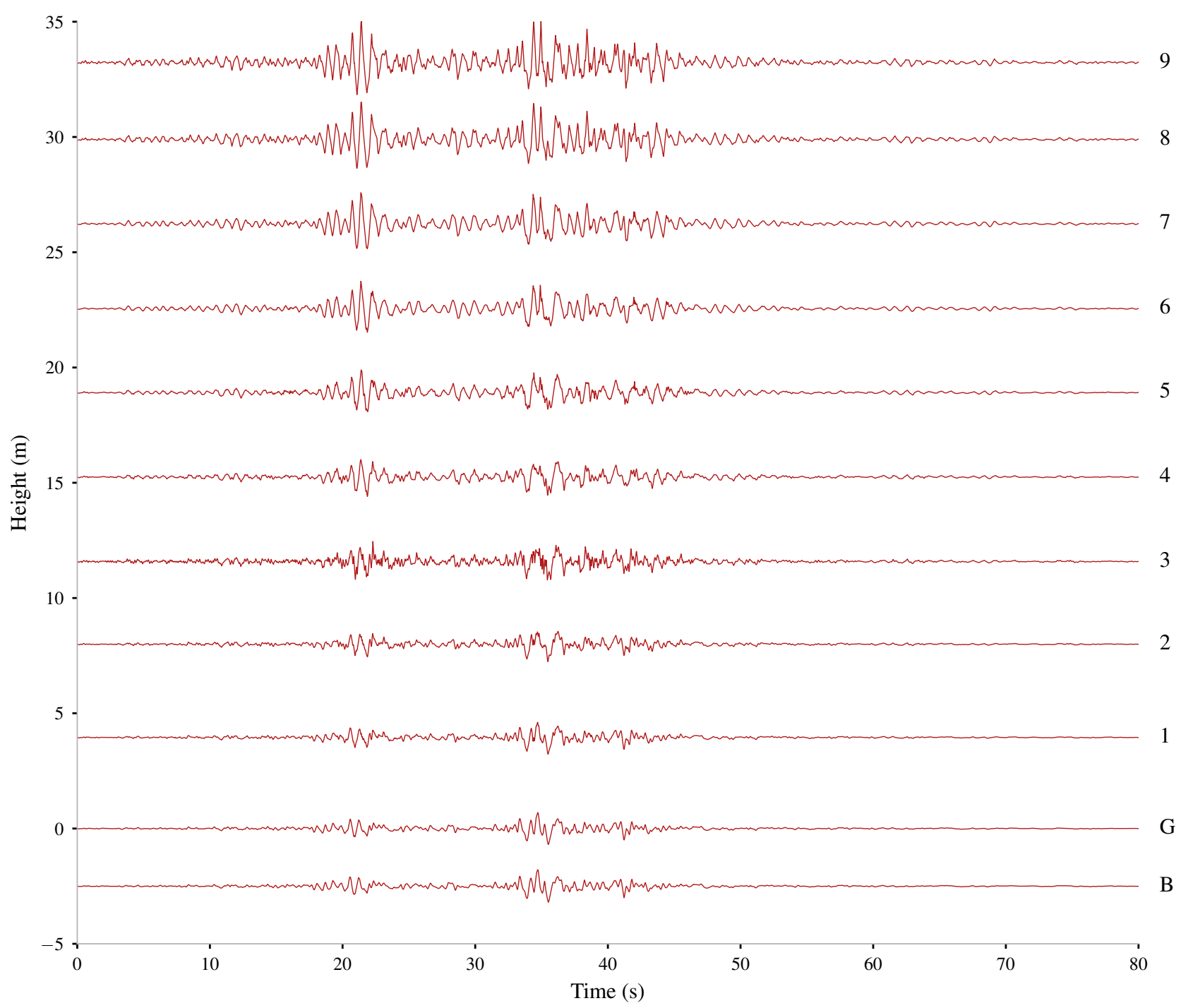

(b) MBIE building

Figure 6: Computed acceleration time series in the transverse direction. 


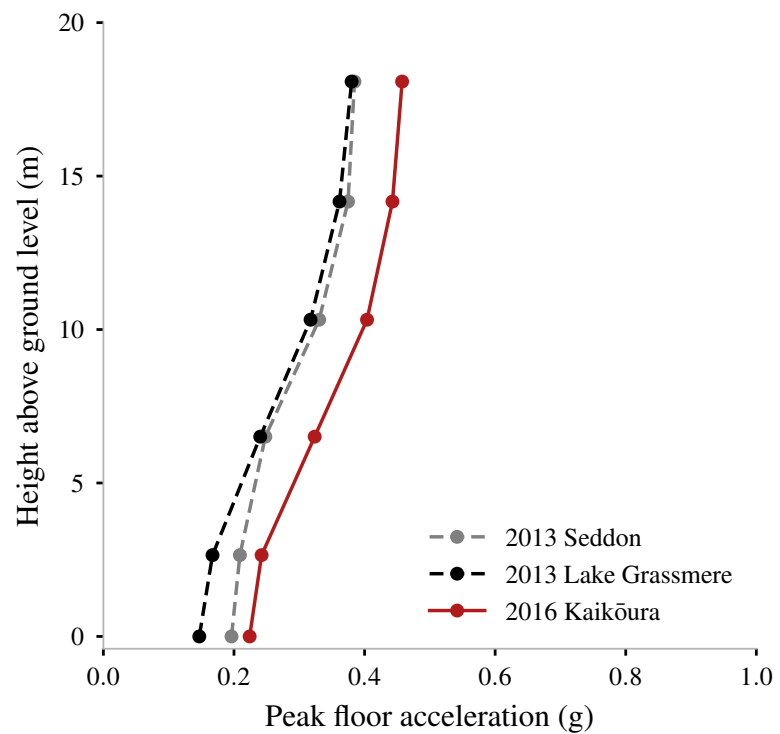

(a) BNZ building (longitudinal direction)

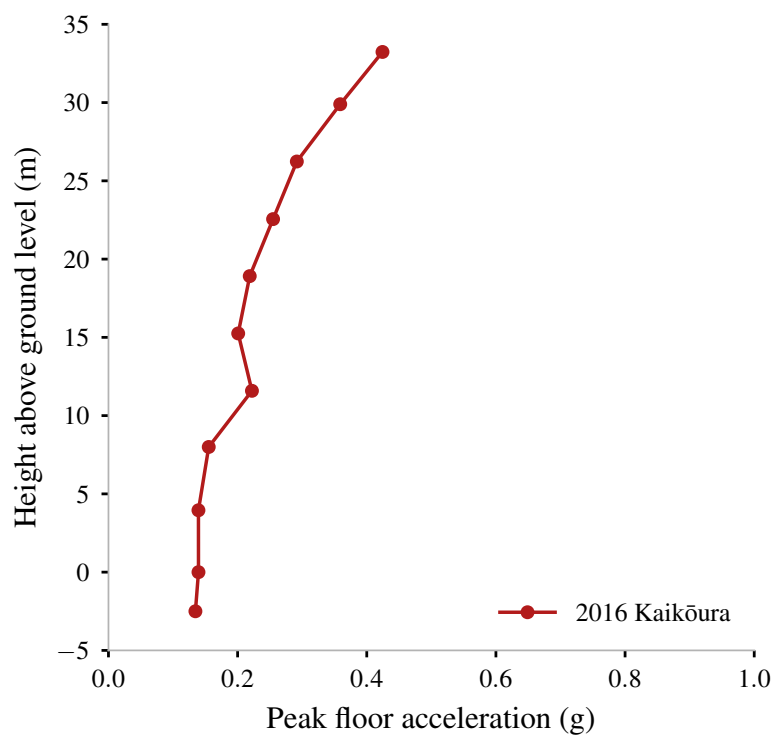

(c) MBIE building (longitudinal direction)

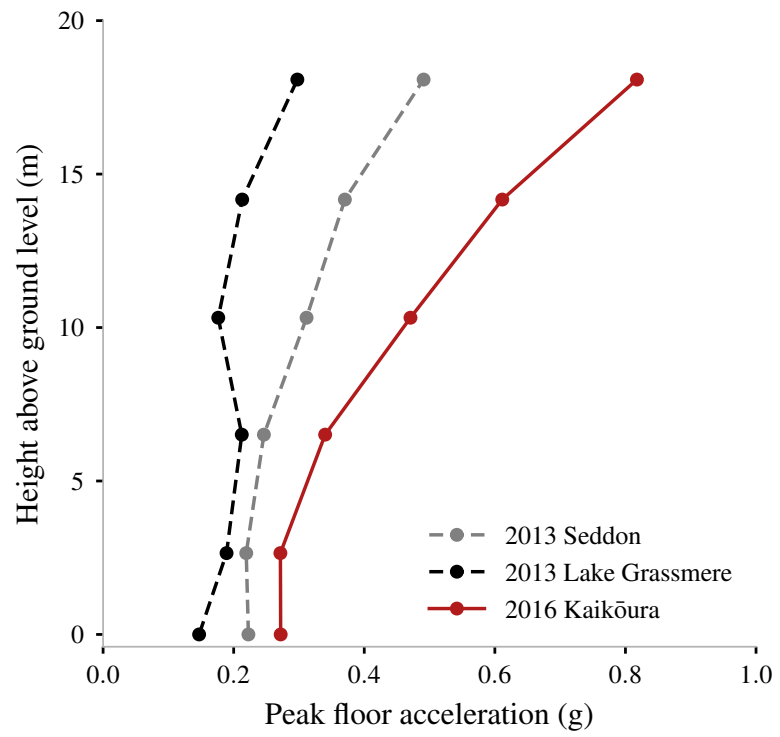

(b) BNZ building (transverse direction)

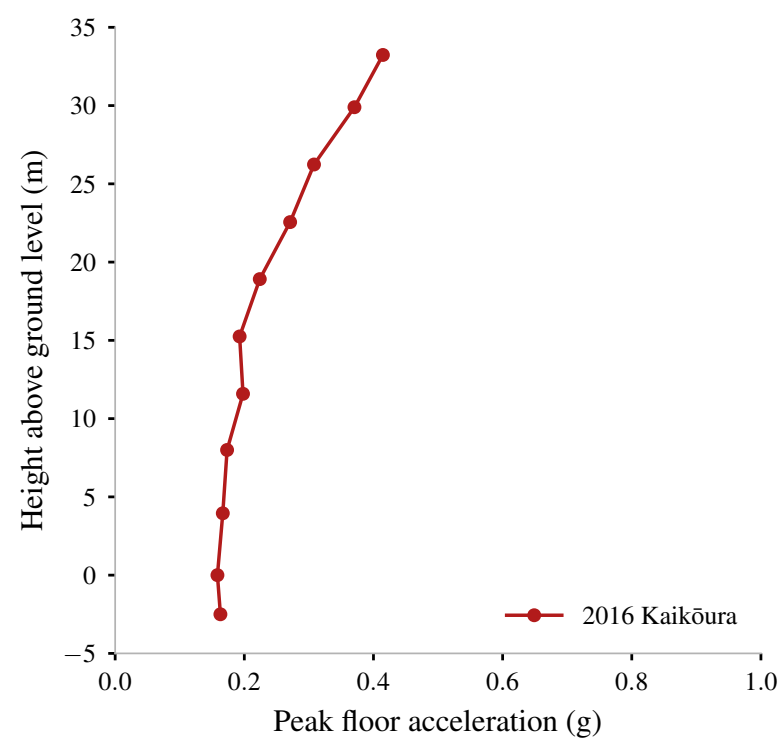

(d) MBIE building (transverse direction)

Figure 7: Peak floor accelerations.

tion of no major structural damage in the building. Observations of damage to drift-sensitive nonstructural components like glass windows and panels in the two buildings, for example, could be contrasted against the computed peak SDRs in an attempt to validate the corresponding fragility functions. Analogous studies comparing the observed damage to acceleration-sensitive components to the computed PFAs, could also potentially be undertaken.

\section{Soil-Structure Interaction}

The significant differences observed between the response spectra of the building-base and free-field ground motions plotted in Figure $2 b$ could be an indicator of the influence of soil-structureinteraction effects on the response of the BNZ building. Alternatively, these differences could also stem from the relatively large horizontal separation of $84 \mathrm{~m}$ between the building-base sensor located at Bay 3, and the free-field sensor located adjacent to Bay 1 (Figure $4 a$ ). The nearly overlapping building-base and free-field response spectra corresponding to the GNS Science and NMIT buildings, on the other hand, indicate the absence of any significant soil-structure-interaction effects for these buildings. Note that the free-field sensor of the GNS Science building failed to record data during the Kaikōura earthquake, but data recorded from the Seddon and Lake Grassmere earthquakes are presented in Figures A2 and A3 of the appendix respectively. Information of this nature is helpful in assigning appropriate boundary conditions during structural model creation.

\section{Vibrational Characteristics}

Finally, if the recorded input ground motion to a building is (i) sufficiently broadband in nature; and (ii) of low enough amplitude to ensure the structural response is within the linear elastic range, the response of the building recorded at a point can be used to compute its frequency response function at that point. The frequency response function provides information regarding the specific frequencies of the input ground motion that are am- 


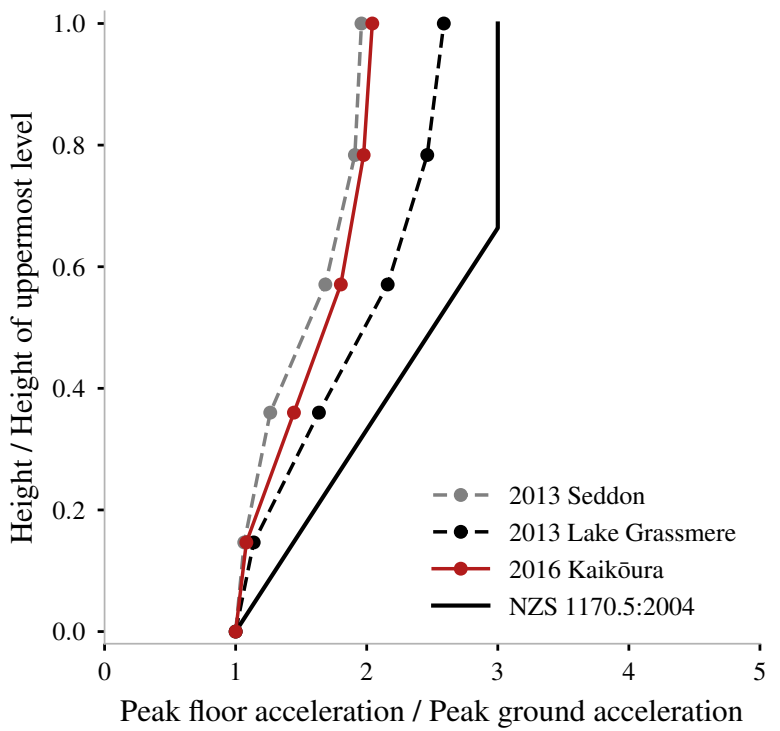

(a) BNZ building (longitudinal direction)

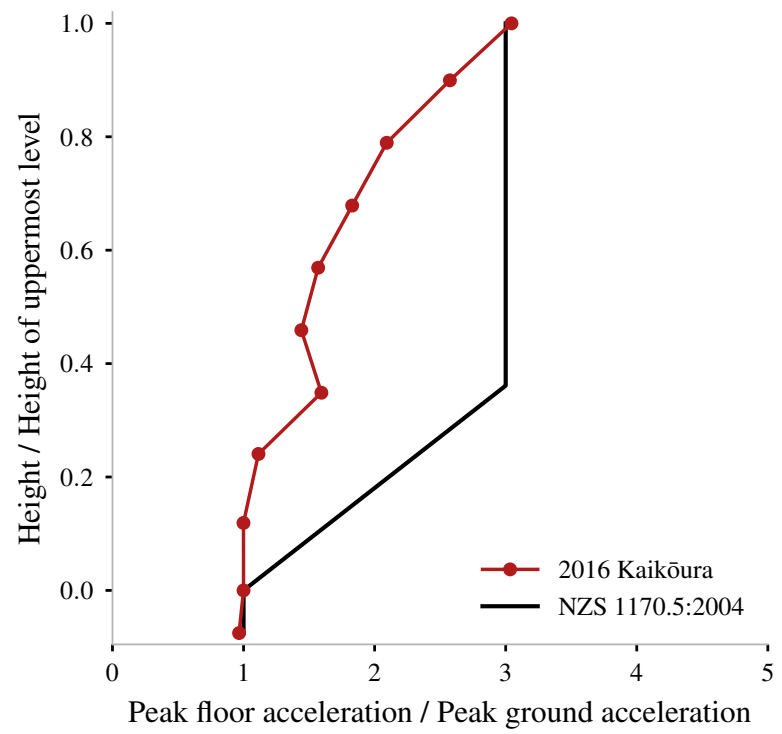

(c) MBIE building (longitudinal direction)

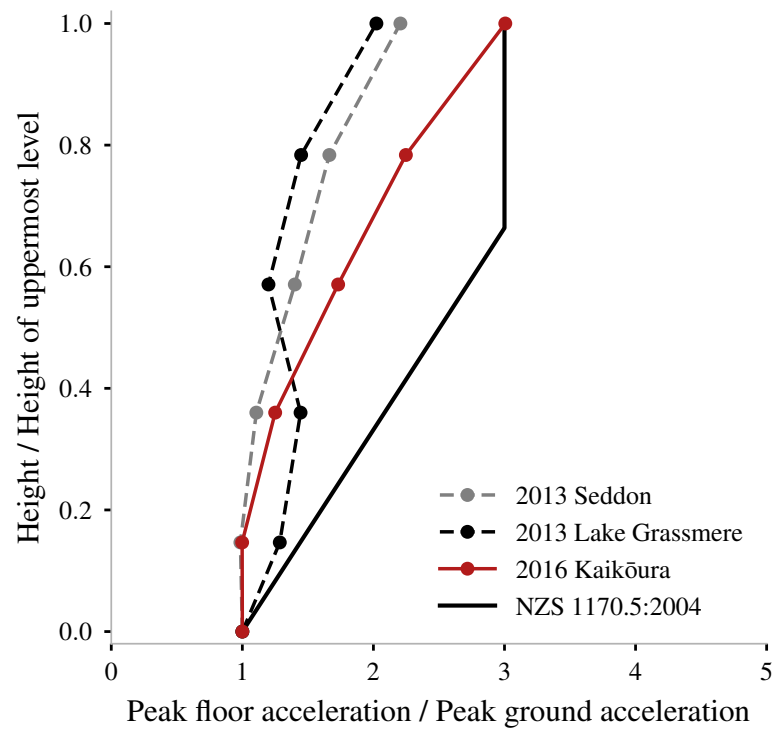

(b) BNZ building (transverse direction)

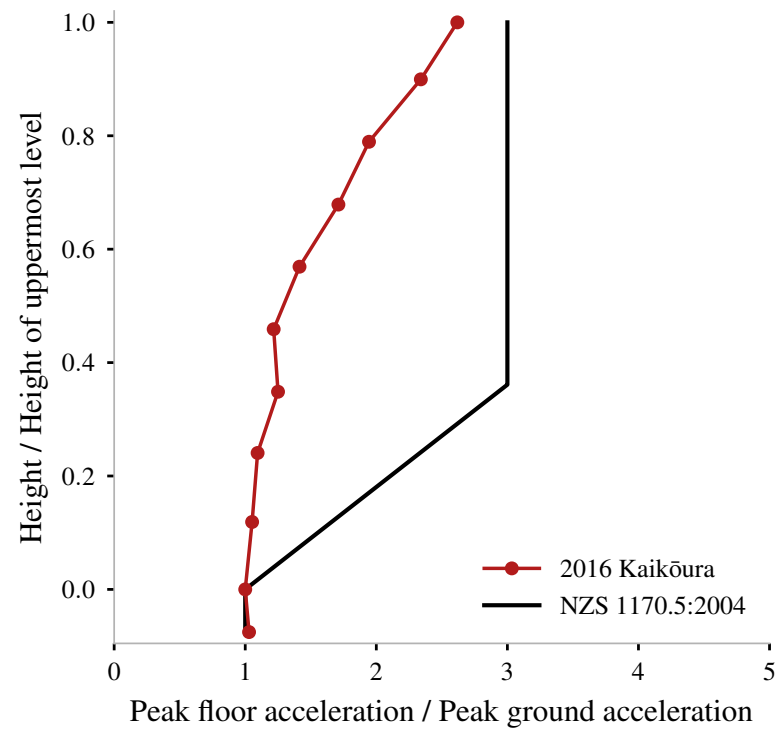

(d) MBIE building (transverse direction)

Figure 8: Peak floor accelerations normalised by the peak ground acceleration.

plified and de-amplified by the building. The fact that buildings amplify frequencies close to their modal frequencies, therefore, is typically reflected in the frequency response function as local maxima corresponding to these frequencies. The frequency response function at a point is computed as the ratio of the Fourier amplitude spectra of the acceleration time series recorded at that point, and at the base of the building. To estimate the fundamental modal frequency, the fact that the first mode deflection increases along the height of the building is exploited by computing the frequency response function at the highest level at which building response was recorded. Smoothed frequency response functions of the BNZ and MBIE buildings are plotted in Figure 11, as functions of period rather than frequency. Their fundamental modal periods inferred from local maxima of the functions are also indicated.

Although this simple, yet effective method is used here to identify the fundamental modal periods, more sophisticated modal identification methods exist to identify periods corresponding to higher modes, as well as the corresponding damping ratios and mode shapes [57, Chapter 21]. It is worth noting that modal characteristics can be estimated more accurately when both the input ground motion and the structural response are measured simultaneously. Alternatively, the application of operational modal analysis techniques [58] to estimate modal characteristics using only ambient vibration data is comparatively less reliable. The fundamental periods computed here were previously used to estimate the intensity of ground motion the buildings were subjected to from the ground motion response spectra in Figure 2. Structural health monitoring applications also commonly track variations in the fundamental period of the structure to detect the onset of structural damage. For instance, the observed elongation in the fundamental period of the BNZ building going from the Seddon and Lake Grassmere earthquakes to the Kaikōura earthquake could serve as an indicator of damage accumulated over successive earthquakes. Similar period elongation phenomena can also be observed from plots corresponding to all three other buildings in Figure A9 of the appendix. Inferences of this nature, 


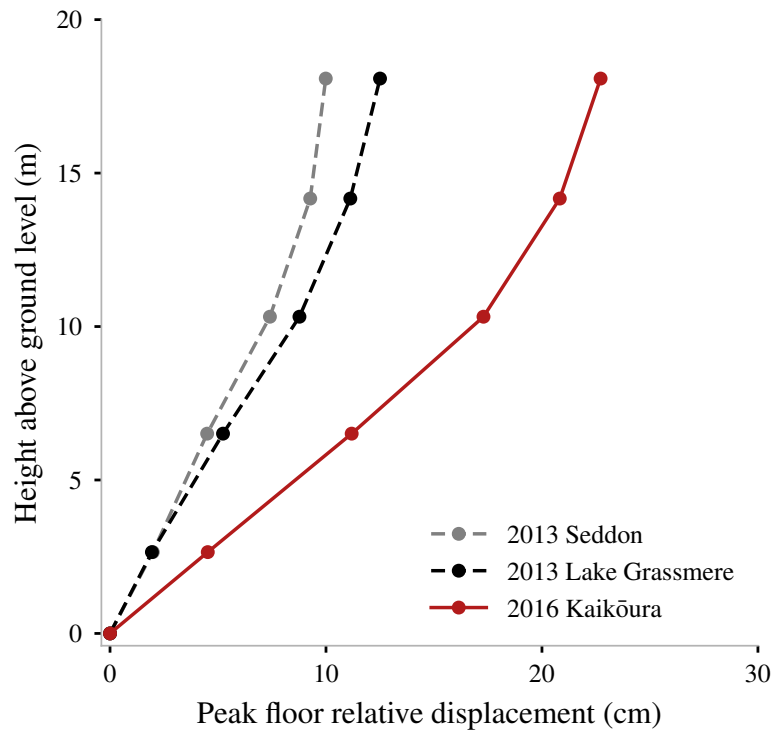

(a) BNZ building (longitudinal direction)

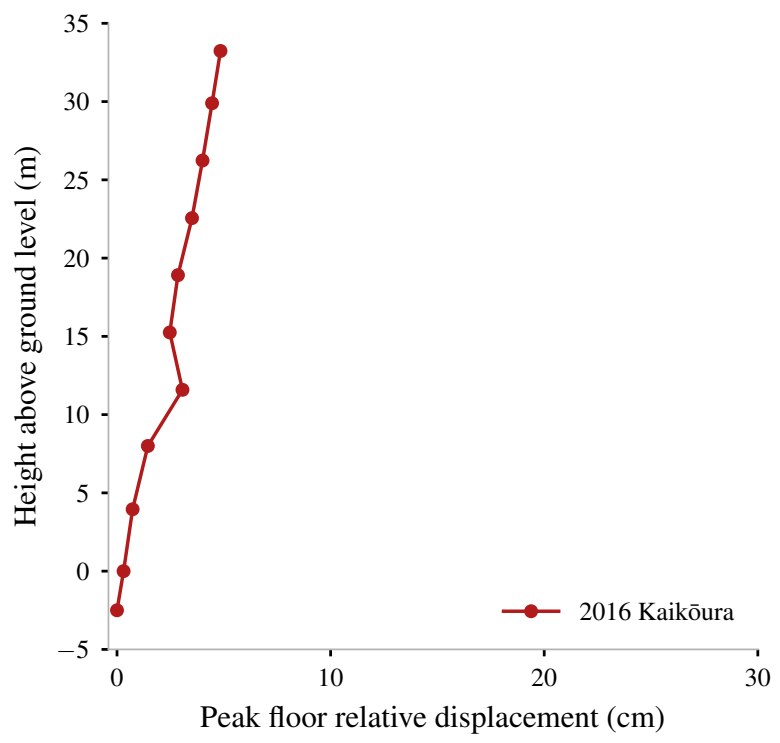

(c) MBIE building (longitudinal direction)

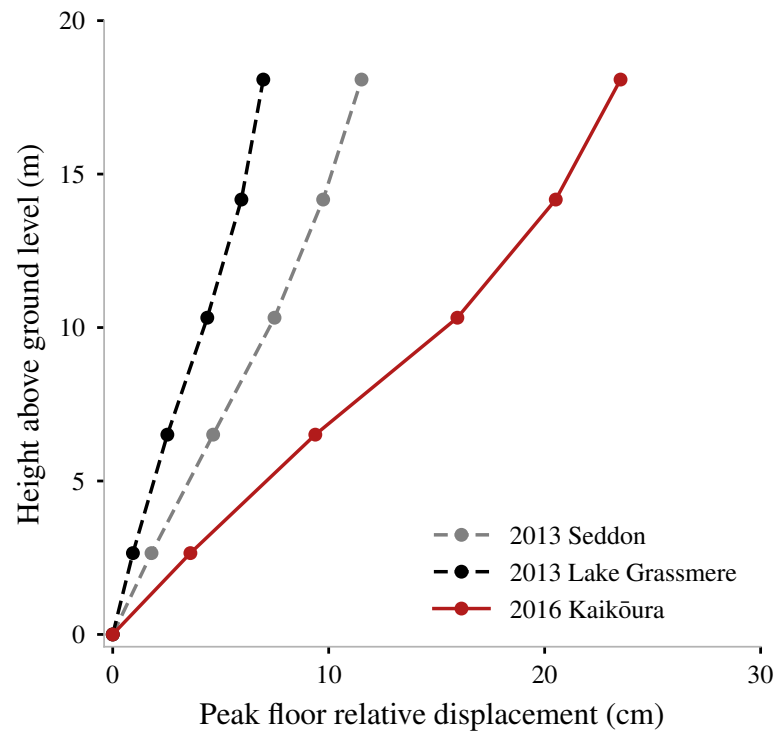

(b) BNZ building (transverse direction)

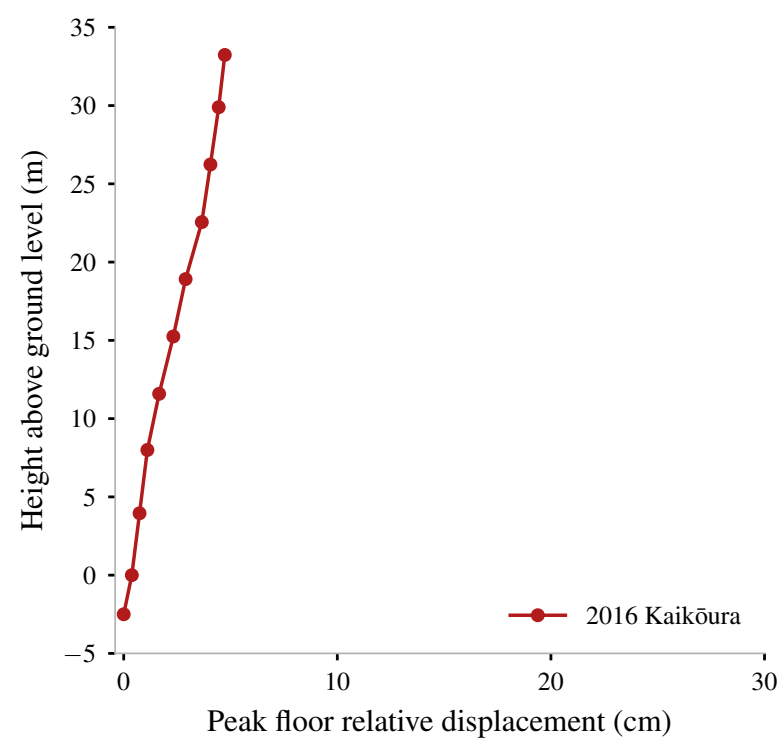

(d) MBIE building (transverse direction)

Figure 9: Peak floor relative displacements.

however, must also take into account the natural variation in the modal periods with operational and environmental conditions.

\section{CONCLUSION}

The responses of five instrumented buildings under the 2016 Kaikōura earthquake were reconstructed using the recordings of accelerometers installed at strategic locations on the buildings as part of the GeoNet Building Instrumentation Programme. The recorded data permitted inference of the acceleration and displacement response of the buildings, and their vibrational characteristics. The computed responses of the Bank of New Zealand (BNZ) Harbour Quays and the Ministry of Business, Innovation, and Employment (MBIE) buildings in Wellington were compared to the intensity of ground motions they were subjected to and the level of damage they experienced. These comparisons were used to highlight the utility of structural response data in the validation of implicit performance objectives of building design codes, structural modelling assumptions, and fragility functions, in addition to their traditional use in structural health monitoring applications.

The ground motions experienced by the buildings in Wellington were rich in long period energy content, especially in the $1-2 \mathrm{~s}$ period range, as a consequence of site amplification effects. The BNZ building was shown to have experienced ground motion of intensity corresponding roughly to its ultimate limit state as per NZS 1170.5:2004. It experienced a maximum peak floor acceleration of around $0.8 \mathrm{~g}$ at its uppermost level, and a maximum peak storey drift ratio of around $1.8 \%$ at its third storey, with both peaks occurring in the transverse direction. The MBIE building, on the other hand, experienced a level of ground motion that could be considered to be in between those corresponding to its serviceability and ultimate limit states. It experienced a maximum peak floor acceleration of around $0.4 \mathrm{~g}$ at its uppermost level, and peak storey drift ratios of around $0.2 \%$ over the entire height of the building, in both the longitudinal and transverse directions. While mostly nonstructural damage was reported in the 


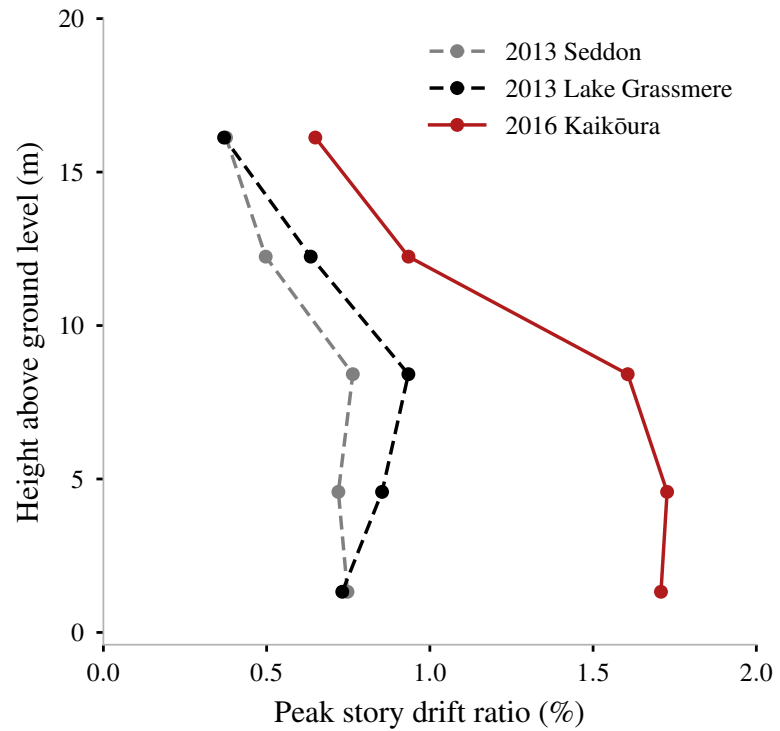

(a) BNZ building (longitudinal direction)

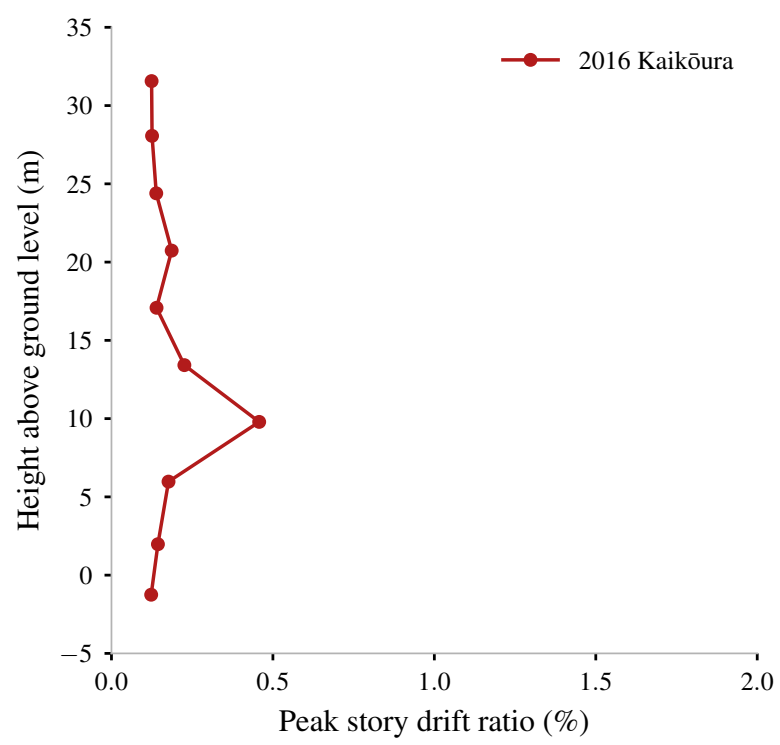

(c) MBIE building (longitudinal direction)

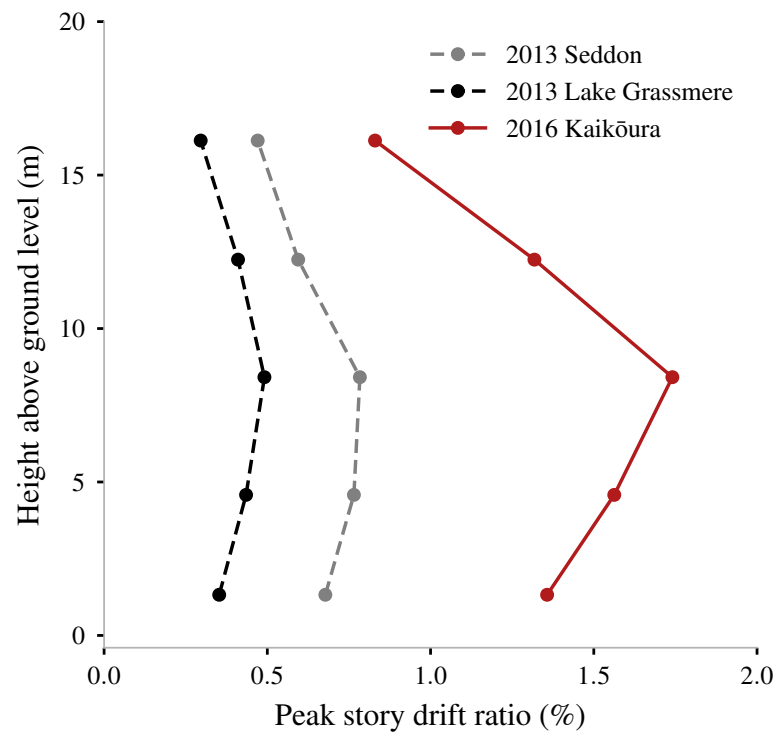

(b) BNZ building (transverse direction)

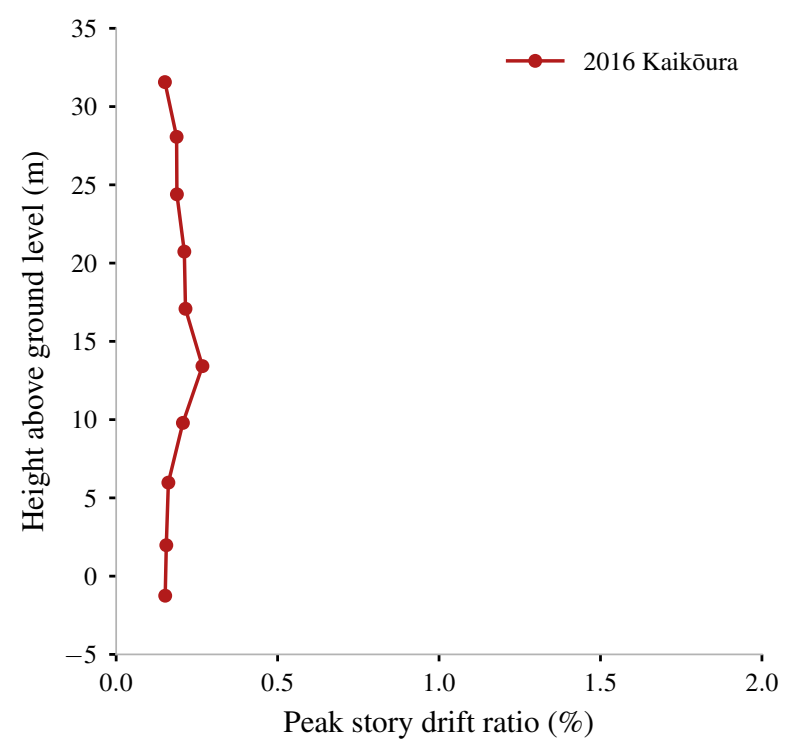

(d) MBIE building (transverse direction)

Figure 10: Peak storey drift ratios.

MBIE building, the BNZ building experienced both structural and nonstructural damage. The intensity of ground motion and level of damage observed in a number of mid and highrise in Wellington, despite being located around $60 \mathrm{~km}$ away from the closest ruptured fault segment, raise concerns regarding the anticipated level of performance under an earthquake of comparable magnitude on the Wellington fault.

Although the monitoring of structural response using accelerometers offers a number of benefits and advantages described above, it is not without its challenges. Instrumentation sparsity, a consequence of the high costs associated with building instrumentation, is a frequently encountered challenge that hinders the interpolation or extrapolation of the motion recorded at discrete locations on the building to compute the motion at other locations. The process of inferring structural displacements by integrating filtered acceleration data twice, is known to be susceptible to errors, often leading to the loss of information related to residual deformations. MEMS accelerometers, which are the mainstays of structural response monitoring systems, are additionally vulnerable to electrical disturbances, which can adversely influence the signal-to-noise ratio of the recorded data. Finally, access to structural response data, and the dissemination of research employing the data, is often impeded by the privacy concerns of the building owners and tenants.

It is, nevertheless, widely acknowledged that the benefits of structural instrumentation vastly outweigh its limitations. Structural response data is considered particularly invaluable in structural model validation efforts that have recently gained impetus. Over the coming years, the GeoNet Building Instrumentation Programme aims to instrument a wider portfolio of buildings in New Zealand, with the objective of bringing its capabilities on par with similar initiatives in countries like the USA and Japan. Data produced by this network of structural sensor arrays will undoubtedly play an important role in enabling important future research that helps advance the state of the Structural Engineering profession. 


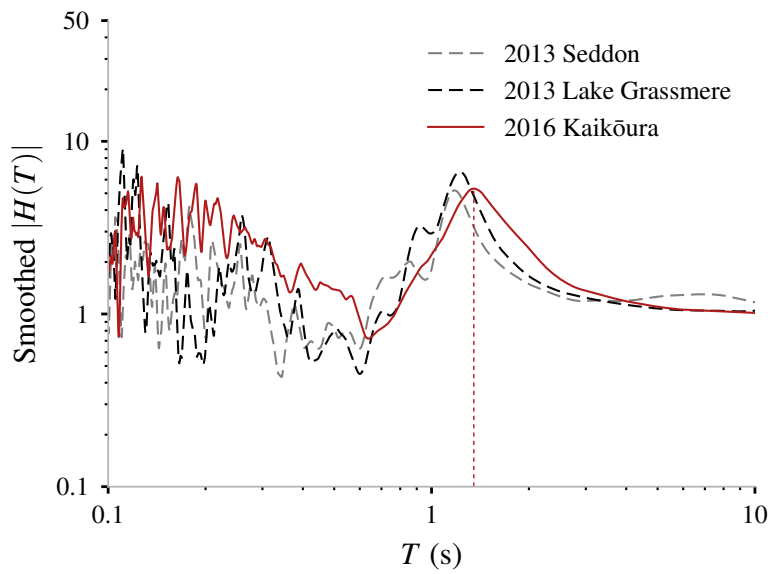

(a) BNZ building (longitudinal direction)

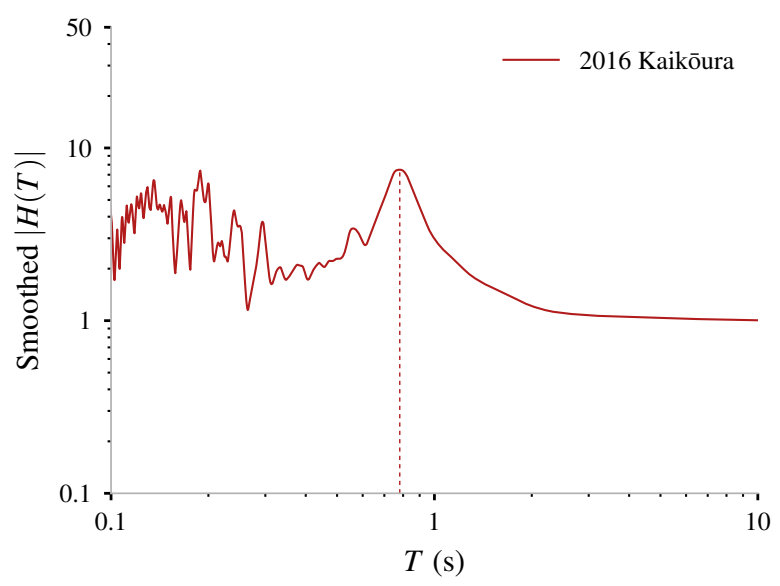

(c) MBIE building (longitudinal direction)

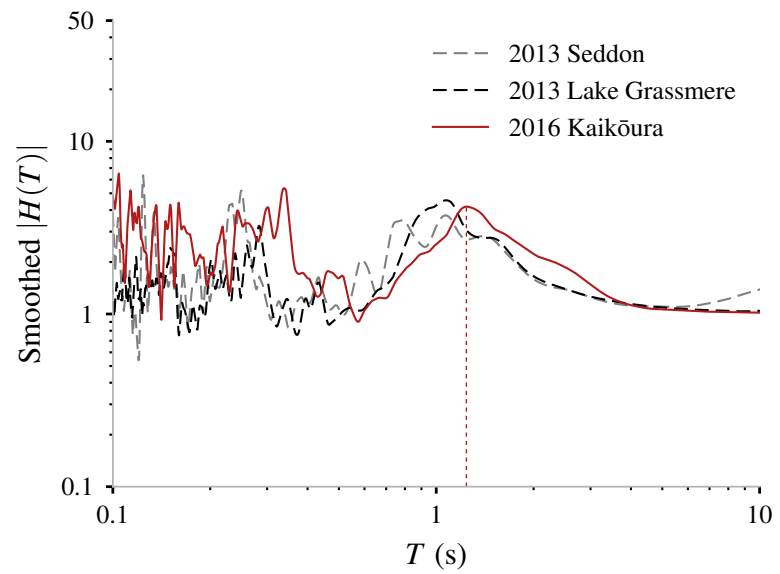

(b) BNZ building (transverse direction)

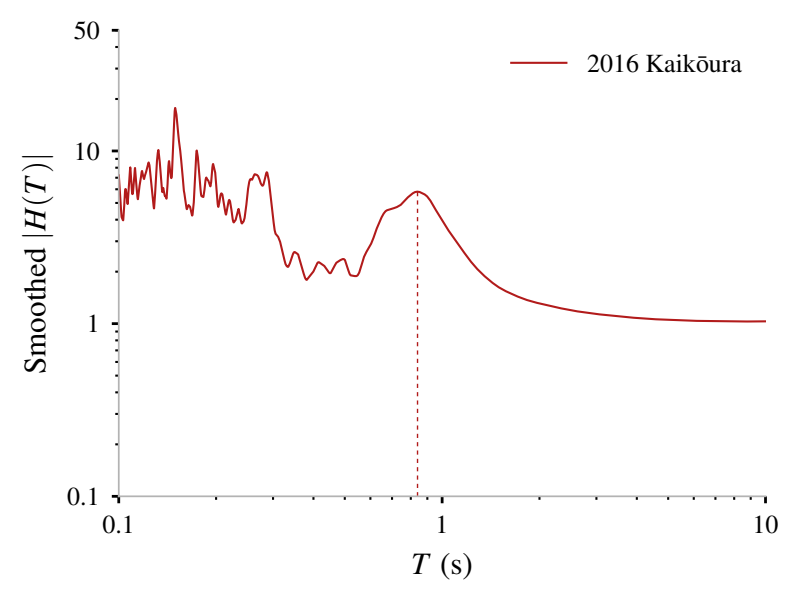

(d) MBIE building (transverse direction)

Figure 11: Smoothed frequency response functions.

\section{ACKNOWLEDGEMENTS}

We thank the owners and tenants of the buildings discussed in this paper for permitting the installation of monitoring sensors on their property, and the dissemination of the recorded building response data. We also acknowledge the insightful and constructive feedback provided by the anonymous reviewer.

This project was (partially) supported by QuakeCoRE, a New Zealand Tertiary Education Commission-funded Centre. This is QuakeCoRE publication number 0174.

\section{REFERENCES}

1 Cousins WJ (1993). "Highlights of 30 years of strong-motion recording in New Zealand". Bulletin of the New Zealand Society for Earthquake Engineering, 26(4): 375-389.

2 Deam BL and Cousins WJ (2002). "Strong-motion instrumentation of buildings in New Zealand". New Zealand Society for Earthquake Engineering Conference, Napier, New Zealand.

3 Uma SR, King A, Cousins WJ and Gledhill K (2011). "The GeoNet building instrumentation programme". Bulletin of the New Zealand Society for Earthquake Engineering, 44(1): 53-63.

4 Zhao JX and Uma SR (2011). “A preliminary analysis on the response of an instrumented building during the 2010 Darfield earthquake - significant effects of soil-structure in- teraction and nonlinear response". 9th Pacific Conference on Earthquake engineering, Auckland, New Zealand.

5 McHattie SA (2013). Seismic response of the UC Physics building in the Canterbury earthquakes. Master's thesis, University of Canterbury, Christchurch, New Zealand.

6 Butt F and Omenzetter P (2014). "Seismic response trends evaluation and finite element model calibration of an instrumented RC building considering soil-structure interaction and non-structural components". Engineering Structures, 65: 111-123, DOI: 10.1016/j.engstruct.2014.01.045.

7 Ma Q, Beskhyroun S, Simkin G, Wotherspoon LM, Ingham J, Cole G, Gebreyohaness A and Sharpe R (2014). "Experimental evaluation of inter-storey drifts during the Cook Strait earthquake sequence". New Zealand Society for Earthquake Engineering Conference, Rotorua, New Zealand.

8 Thomson EM and Bradley BA (2014). "Preliminary analysis of instrumented Wellington building responses in the July/August 2013 Seddon/Lake Grassmere earthquakes". New Zealand Society for Earthquake Engineering Conference, Rotorua, New Zealand.

9 Simkin G, Beskhyroun S, Ma Q, Wotherspoon LM and Ingham J (2015). "Measured response of instrumented buildings during the 2013 Cook Strait Earthquake Sequence". Bulletin of the New Zealand Society for Earthquake Engineering, 48(4).

10 Bradley BA, Wotherspoon LM and Kaiser AE (2017). 
"Ground motion and site effect observations in the Wellington region from the 2016 Mw7.8 Kaikoura, New Zealand earthquake". Bulletin of the New Zealand Society for Earthquake Engineering, 50(2): 94-105.

11 New Zealand Standard (2004). Structural Design Actions Part 5: Earthquake Actions - New Zealand. Tech. Rep. NZS 1170.5, Standards New Zealand, Wellington, New Zealand.

12 Skolnik DA and Wallace JW (2010). "Critical Assessment of Interstory Drift Measurements". Journal of Structural Engineering, 136(12): 1574-1584, DOI: 10.1061/(ASCE) ST.1943-541X.0000255.

13 de la Llera JC and Chopra AK (1995). "Evaluation of seismic code provisions using strong-motion building records from the 1994 Northridge earthquake". SMIP95 Seminar on Seismological and Engineering Implications of Recent Strong-Motion Data, San Francisco, CA.

14 Trifunac MD and Todorovska MI (2001). "Recording and interpreting earthquake response of fullscale structures". M Erdik, M Çelebi, V Mihailov and N Apaydin (eds.) Strong Motion Instrumentation for Civil Engineering Structures, Springer Netherlands, Dordrecht, Netherlands, ISBN 9780-7923-6917-2, pp. 131-155, DOI: 10.1007/978-94-0100696-5_9.

15 Ivanović S, Trifunac M, Novikova E, Gladkov A and Todorovska M (2000). "Ambient vibration tests of a sevenstory reinforced concrete building in Van Nuys, California, damaged by the 1994 Northridge earthquake". Soil Dynamics and Earthquake Engineering, 19(6): 391-411, DOI: 10.1016/S0267-7261(00)00025-7.

16 Farrar CR and Worden K (2007). "An introduction to structural health monitoring". Philosophical Transactions of the Royal Society A: Mathematical, Physical and Engineering Sciences, 365(1851): 303-315, DOI: 10.1098/rsta.2006. 1928.

17 Worden K, Farrar CR, Manson G and Park G (2007). "The fundamental axioms of structural health monitoring". Proceedings of the Royal Society A: Mathematical, Physical and Engineering Sciences, 463(2082): 1639-1664, DOI: 10.1098/rspa.2007.1834.

18 Farrar CR and Worden K (2013). Structural Health Monitoring: A Machine Learning Perspective. John Wiley \& Sons, Ltd, Chichester, UK, ISBN 978-1-119-99433-6, 631 pp.

19 Beskhyroun S, Ma Q and Wotherspoon LM (2017). "Development of a monitoring system for damage assessment of buildings after earthquakes". 16th World Conference on Earthquake Engineering, Santiago, Chile.

$20 \mathrm{Li}$ YR and Jirsa JO (1998). "Nonlinear Analyses of an Instrumented Structure Damaged in the 1994 Northridge Earthquake". Earthquake Spectra, 14(2): 265-283, DOI: 10.1193/ 1.1585999 .

21 Kunnath SK, Nghiem Q and El-Tawil S (2004). "Modeling and Response Prediction in Performance-Based Seismic Evaluation: Case Studies of Instrumented Steel MomentFrame Buildings". Earthquake Spectra, 20(3): 883-915, DOI: 10.1193/1.1774181.

22 Brownjohn JMW and Xia PQ (2000). "Dynamic Assessment of Curved Cable-Stayed Bridge by Model Updating". Journal of Structural Engineering, 126(2): 252-260, DOI: 10.1061/(ASCE)0733-9445(2000)126:2(252).

23 Skolnik DA, Lei Y, Yu E and Wallace JW (2006). "Identification, Model Updating, and Response Prediction of an Instrumented 15-Story Steel-Frame Building”. Earthquake Spectra, 22(3): 781-802, DOI: 10.1193/1.2219487.
24 Michel C, Guéguen P, El Arem S, Mazars J and Kotronis $P$ (2009). "Full-scale dynamic response of an RC building under weak seismic motions using earthquake recordings, ambient vibrations and modelling". Earthquake Engineering \& Structural Dynamics, 39(4): 419-441, DOI: 10.1002/eqe. 948.

25 Hori M, Ichimura T, Wijerathne L, Ohtani H, Chen J and Fujita K (2017). "Integrated Earthquake Simulation for Hazard and Disaster Assessment of Urban Area Using High Performance Computing". 16th World Conference on Earthquake Engineering, Santiago, Chile.

26 USGS (2016). "M 7.8 - 54km NNE of Amberley, New Zealand". URL: https://earthquake.usgs.gov/earthquakes/ eventpage/us 1000778i, Accessed 2017-03-02.

27 Kaiser AE, Balfour N, Fry B, Holden C, Litchfield NJ, Gerstenberger M, D'Anastasio E, Horspool N, McVerry G, Ristau J, Bannister S, Christophersen A, Clark K, Power W, Rhoades DA, Massey C, Hamling I, Wallace L, Mountjoy JJ, Kaneko Y, Benites R, Van Houtte C, Dellow S, Wotherspoon LM, Elwood KJ and Gledhill K (2017). “The 2016 Kaikōura, New Zealand, Earthquake: Preliminary Seismological Report". Seismological Research Letters, 88(3): 727 739, DOI: $10.1785 / 0220170018$.

28 Bradley BA, Razafindrakoto HNT and Polak V (2017). "Ground motion observations from the 14 November 2016 Mw7.8 Kaikoura, New Zealand earthquake and insights from broadband simulations". Seismological Research Letters, 88(3), DOI: $10.1785 / 0220160225$.

29 Stirling M, Litchfield NJ, Villamor P, Van Dissen RJ, Nicol A, Pettinga JR, Barnes PM, Langridge R, Little T, Barrell DJA, Mountjoy JJ, Ries WF, Rowland J, Fenton C, Hamling IJ, Asher C, Barrier A, Benson A, Bischoff A, Borella J, Carne R, Cochran UA, Cockroft M, Cox SC, Duke G, Fenton F, Gasston C, Grimshaw C, Hale D, Hall B, Hao KX, Hatem A, Hemphill-Haley M, Heron DW, Howarth J, Juniper Z, Kane T, Kearse J, Khajavi N, Lamarche G, Lawson S, Lukovic B, Madugo C, Manousakis I, McColl S, Noble D, Pedley K, Sauer K, Stah T, Strong DT, Townsend DB, Toy V, Villeneuve M, Wandres A, Williams J, Woelz S and Zinke R (2017). "The Mw7.8 2016 Kaikōura earthquake: Surface fault rupture and seismic hazard context". Bulletin of the New Zealand Society for Earthquake Engineering, 50(2): 73-84.

30 Murashev A and Palmer S (1998). "Geotechnical issues associated with development on Wellington's waterfront". Transactions of the Institution of Professional Engineers New Zealand: Civil Engineering, 25(1): 38-46.

31 Trifunac MD and Brady AG (1975). "A study on the duration of strong earthquake ground motion". Bulletin of the Seismological Society of America, 65(3): 581-626.

32 Henry RS, Dizhur D, Elwood KJ, Hare J and Brundson D (2017). "Damage to concrete buildings with precast floors during the 2016 Kaikoura earthquake". Bulletin of the New Zealand Society for Earthquake Engineering, 50(2): 174186.

33 GeoNet (2017). "GeoNet Structural Array Data - Instrumentation and Locations". URL: http://info.geonet.org.nz/ display/appdata/Instrumentation+and+Locations, Accessed 2017-03-02.

34 Semmens S, Perrin ND, Dellow G and Van Dissen RJ (2011). "Site subsoil classification of Wellington City". 9th Pacific Conference on Earthquake engineering, Auckland, New Zealand.

35 Boon D, Perrin ND, Dellow GD, Van Dissen RJ and Lukovic 
B (2011). "NZS1170.5:2004 Site Subsoil Classification of Lower Hutt". 9th Pacific Conference on Earthquake Engineering, Auckland, New Zealand.

36 Perrin ND, Heron DW, Kaiser AE and Van Houtte C (2015). "Vs30 and NZS 1170.5 site class maps of New Zealand". New Zealand Society for Earthquake Engineering Conference, Rotorua, New Zealand.

37 Aurecon (2014). "15 Stout Street, New Zealand”. Accessed 2017-03-15

38 Cubrinovski M, Bray JD, de la Torre C, Olsen MJ, Bradley BA, Chiaro G, Stocks E and Wotherspoon LM (2017). "Liquefaction effects and associated damages observed at the Wellington CentrePort from the 2016 Kaikōura earthquake". Bulletin of the New Zealand Society for Earthquake Engineering, 50(2): 152-173.

39 The Dominion Post (2013). "BNZ Harbour Quays building closed after quake". URL: http://www.stuff.co.nz/dominionpost/news/wellington/8958879/BNZ-Harbour-Quaysbuilding-closed-after-quake, Accessed 2017-03-11.

40 Schouten H (2013). "Newer building one of worst hit in quake". The Dominion Post, URL: http: //www.stuff.co.nz/dominion-post/news/8978371/Newerbuilding-one-of-worst-hit-in-quake, Accessed 2017-03-11.

41 Rutherford H (2016). "BNZ says if staff had followed quake procedure 'they should have been okay"'. Stuff.co.nz, URL: http://www.stuff.co.nz/business/86757342/bnz-saysif-staff-had-followed-quake-procedure-they-should-havebeen-okay, Accessed 2017-03-11.

42 Rutherford H and George D (2016). "CentrePort-owned BNZ building, damaged in 2013 quake, appears extensively damaged". Stuff.co.nz, URL: http://www.stuff.co. nz/business/86428277/centreportowned-bnz-buildingdamaged-in-2013-quake-appears-extensively-damaged, Accessed 2017-03-11.

43 McBeth P (2016). "BNZ says Wellington office will be closed for months". The National Business Review, URL: https://www.nbr.co.nz/article/bnz-says-wellingtonoffice-will-be-closed-months-b-196863, Accessed 2017-0311.

44 Williams K (2017). "How is Wellington coping 100 days on from the 7.8 magnitude Kaikoura quake?" Stuff.co.nz, URL: http://www.stuff.co.nz/national/nzearthquake/89604340/how-is-wellington-coping-100days-on-from-the-78-magnitude-kaikoura-quake, Accessed 2017-03-11.

45 New Zealand Standard (2004). Structural Design Actions Part 5: Earthquake Actions - New Zealand - Commentary. Tech. Rep. AS/NZS 1170.5 Supp 1, Standards New Zealand,
Wellington, New Zealand.

46 Uma SR, Cousins WJ, Young J and Barker PR (2010). Seismic instrumentation in BNZ Building, Wellington. Tech. Rep. 2010/29, GNS Science, Lower Hutt, New Zealand.

47 Burt GH (1939). "Departmental Building (Defence House), Stout St, Wellington". Te Papa (C.002640), URL: http:// collections.tepapa.govt.nz/object/118529, Accessed 201703-20.

48 Haselton CB, Baker JW, Liel AB and Deierlein GG (2011). "Accounting for Ground-Motion Spectral Shape Characteristics in Structural Collapse Assessment through an Adjustment for Epsilon". Journal of Structural Engineering, 137(3): 332-344, DOI: 10.1061/(ASCE)ST.1943-541X.0000103.

49 Tatham H and Jury R (2016). Level 2 rapid assessment. Tech. Rep. NZ1-6082552-13 1.8, Beca, Wellington, New Zealand.

50 Holden T (2016). Post Earthquake Preliminary Level 2 Assessment. Tech. Rep. 254425, Aurecon, Wellington, New Zealand.

51 Boore DM (2005). "On Pads and Filters: Processing StrongMotion Data". Bulletin of the Seismological Society of America, 95(2): 745-750, DOI: 10.1785/0120040160.

52 Boore DM and Bommer JJ (2005). "Processing of strongmotion accelerograms: needs, options and consequences". Soil Dynamics and Earthquake Engineering, 25(2): 93-115, DOI: 10.1016/j.soildyn.2004.10.007.

53 Naeim F, Lee H, Bhatia H, Hagie S and Skliros K (2005). CSMIP instrumented building response analysis and 3-D visualization system (CSMIP-3DV). Tech. rep., John A. Martin and Associates, Inc., Los Angeles, CA.

54 Drake RM and Bragagnolo LJ (2000). "Model Code Design Force Provisions for Elements of Structures and Nonstructural Components". Earthquake Spectra, 16(1): 115-125, DOI: 10.1193/1.1586086.

55 Rodriguez ME, Restrepo JI and Carr AJ (2002). "Earthquakeinduced floor horizontal accelerations in buildings". Earthquake Engineering \& Structural Dynamics, 31(3): 693-718, DOI: $10.1002 /$ eqe.149.

56 Miranda E and Taghavi S (2005). "Approximate Floor Acceleration Demands in Multistory Buildings. I: Formulation". Journal of Structural Engineering, 131(2): 203-211, DOI: 10.1061/(ASCE)0733-9445(2005)131:2(203).

57 Piersol AG and Paez TL (2009). Harris' Shock and Vibration Handbook. McGraw-Hill, New York, NY, 6 ed., ISBN 9780071633437.

58 Brincker R and Ventura CE (2015). Introduction to Operational Modal Analysis. John Wiley \& Sons, Ltd, Chichester, UK, ISBN 9781118535141, DOI: 10.1002/9781118535141. 